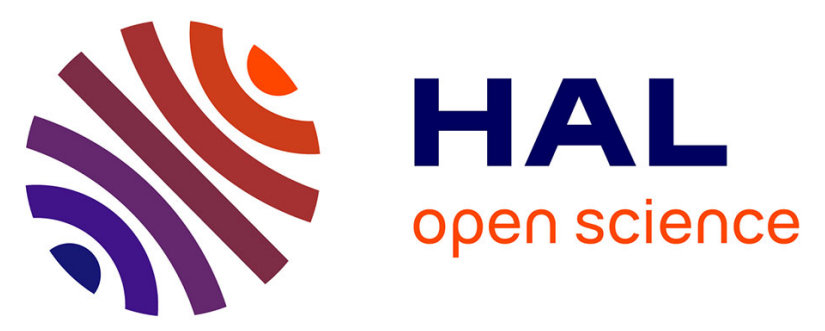

\title{
Manganese distribution in the Mn-hyperaccumulator Grevillea meisneri from New Caledonia
}

Camille Bihanic, Eddy Petit, Roseline Perrot, Lucie Cases, Armelle Garcia, Franck Pelissier, Cyril Poullain, Camille Rivard, Martine Hossaert-Mckey, Doyle Mckey, et al.

\section{To cite this version:}

Camille Bihanic, Eddy Petit, Roseline Perrot, Lucie Cases, Armelle Garcia, et al.. Manganese distribution in the Mn-hyperaccumulator Grevillea meisneri from New Caledonia. Scientific Reports, 2021, 11, pp.23780. 10.1038/s41598-021-03151-9 . hal-03481093

\section{HAL Id: hal-03481093 https://hal.science/hal-03481093}

Submitted on 15 Dec 2021

HAL is a multi-disciplinary open access archive for the deposit and dissemination of scientific research documents, whether they are published or not. The documents may come from teaching and research institutions in France or abroad, or from public or private research centers.
L'archive ouverte pluridisciplinaire HAL, est destinée au dépôt et à la diffusion de documents scientifiques de niveau recherche, publiés ou non, émanant des établissements d'enseignement et de recherche français ou étrangers, des laboratoires publics ou privés. 


\title{
OPEN Manganese distribution in the Mn-hyperaccumulator Grevillea meisneri from New Caledonia
}

\author{
Camille Bihanic ${ }^{1}$, Eddy Petit ${ }^{2}$, Roseline Perrot ${ }^{3}$, Lucie Cases $^{1}$, Armelle Garcia ${ }^{1}$, \\ Franck Pelissier ${ }^{1}$, Cyril Poullain ${ }^{1}$, Camille Rivard ${ }^{4,5}$, Martine Hossaert-McKey ${ }^{1}$, \\ Doyle McKey $^{6}$ \& Claude Grison ${ }^{1 凶}$
}

New Caledonian endemic Mn-hyperaccumulator Grevillea meisneri is useful species for the preparation of ecocatalysts, which contain $\mathrm{Mn}-\mathrm{Ca}$ oxides that are very difficult to synthesize under laboratory conditions. Mechanisms leading to their formation in the ecocatalysts are unknown. Comparing tissue-level microdistribution of these two elements could provide clues. We studied tissue-level distribution of $\mathrm{Mn}, \mathrm{Ca}$, and other elements in different tissues of $\mathrm{G}$. meisneri using micro-X-Ray Fluorescence-spectroscopy ( $\mu$ XRF), and the speciation of Mn by micro-X-ray Absorption Near Edge Structure ( $\mu$ XANES), comparing nursery-grown plants transplanted into the site, and similar-sized plants growing naturally on the site. Mirroring patterns in other Grevillea species, Mn concentrations were highest in leaf epidermal tissues, in cortex and vascular tissues of stems and primary roots, and in phloem and pericycle-endodermis of parent cluster roots. Strong positive $\mathrm{Mn} / \mathrm{Ca}$ correlations were observed in every tissue of $G$. meisneri where $\mathrm{Mn}$ was the most concentrated. Mn foliar speciation confirmed what was already reported for $\mathrm{G}$. exul, with strong evidence for carboxylate counter-ions. The co-localization of $\mathrm{Ca}$ and $\mathrm{Mn}$ in the same tissues of $\mathrm{G}$. meisneri might in some way facilitate the formation of mixed $\mathrm{Ca}-\mathrm{Mn}$ oxides upon preparation of Eco-CaMnOx ecocatalysts from this plant. Grevillea meisneri has been successfully used in rehabilitation of degraded mining sites in New Caledonia, and in supplying biomass for production of ecocatalysts. We showed that transplanted nursery-grown seedlings accumulate as much $\mathrm{Mn}$ as do spontaneous plants, and sequester $\mathrm{Mn}$ in the same tissues, demonstrating the feasibility of large-scale transplantation programs for generating Mn-rich biomass.

More than 700 plant species worldwide are so far known to be hyperaccumulators of metals. These plants can accumulate heavy metals at levels 100 to 1000 times greater than in non-accumulating species, and are distinguished from "accumulators", species that accumulate metals at high levels of without being a hyperaccumulator ${ }^{1}$. Ten metal and two metalloid (rare earth elements) elements are known to be hyperaccumulated, with reports for Ni being the most frequent (130 genera, 532 species), followed by Cu (43 genera, 53 species), Co ( 34 genera, 42 species), Mn (24 genera, 42 species) and Zn (12 genera, 20 species) ${ }^{2}$. Along with $\mathrm{Cuba}^{3,4}$, New Caledonia is considered to be a global metallophyte 'hot-spot' ${ }^{\prime 5}$. As elsewhere, Ni-hyperaccumulators predominate, with 12 genera and 65 species $^{6}$, but Mn-hyperaccumulators are also frequent (8 genera, 11 species) ${ }^{7}$. However, new hyperaccumulating species still remain to be discovered, as shown by recent research in this field ${ }^{8,9}$.

Metal hyper-accumulators are potentially useful resources in several contexts. They provide novel ecocatalysts with numerous industrial applications in 'green' and sustainable chemistry ${ }^{10-14}$. These polymetallic catalytic materials are used in organic synthesis to generate bio-sourced molecules with high added value and

\footnotetext{
${ }^{1}$ Laboratoire de Chimie Bio-Inspirée et d'Innovations Écologiques, ChimEco, UMR 5021, CNRS-Université de Montpellier, Cap Delta, 1682 Rue de la Valsière, 34790 Grabels, France. ${ }^{2}$ Institut Européen des Membranes, IEM-UMR 5635, ENSCM, CNRS-Université de Montpellier, 34090 Montpellier, France. ${ }^{3}$ Service des Laboratoires Officiels Vétérinaires Agroalimentaires et Phytosanitaires de Nouvelle-Calédonie, DAVAR, New Caledonia, France. ${ }^{4}$ Synchrotron SOLEIL, 91190 Saint-Aubin, France. ${ }^{5}$ TRANSFORM, UAR 1008, INRAE, 44316 Nantes, France. ${ }^{6}$ CEFE, Université de Montpellier, CNRS, EPHE, IRD, 1919 Route de Mende, 34293 Montpellier cedex 5, France. ${ }^{\square}$ email: claude.grison@cnrs.fr
} 
platform molecules as petrochemistry substitutes. Adapted to metalliferous soils, metal hyper-accumulators are also potentially useful in the revegetation of mining sites. However, despite the high number of reported (hyper) accumulating species, only a few have proven to be useful in the phytoremediation of mining sites. For example, although Ni-hyperaccumulators account for about $70 \%$ of known hyperaccumulators worldwide ${ }^{2}$, few of them are usable in mining restoration at large scale. Alyssum murale (Brassicaceae) has been successfully used in revegetation of $\mathrm{Ni}$-contaminated mining sites in Oregon, $\mathrm{USA}^{15-17}$, but this European plant has also become an invasive species there ${ }^{18}$, demonstrating one advantage of using native plants in revegetation. In New Caledonia, our group demonstrated the potential of the endemic Ni-hyperaccumulator Gessois pruinosa (Cunoniaceae) in restoration after mining ${ }^{19}$. Accumulators of $\mathrm{Cu}$ and $\mathrm{Co}$ have been used in restoration of mining sites in Katanga Province, Democratic Republic of Congo ${ }^{20} . \mathrm{Zn}$ is another metal hyperaccumulated by some plants ${ }^{2}$. As shown by our work, they provide unique eco-catalysts ${ }^{21,22}$, but their generally low biomass and modest root systems limit their usefulness in revegetation ${ }^{21}$. Finally, 22 plant species are currently known to accumulate or hyperaccumulate rare earth elements (REE) ${ }^{23}$. REE-hyperaccumulators were discovered only recently, and so far have not been used in post-mining restoration.

$\mathrm{Mn}$-(hyper)accumulating species have proved particularly suitable for use in revegetation of mining sites and valorization in "green" chemistry, for two reasons. First, they include trees, whose biomass production greatly exceeds that of Zn-, Ni- or REE-(hyper)accumulators. Second, of these metallic elements, Mn(II) is the only one to be in agreement with REACH regulation (Registration, Evaluation, Authorization and restriction of CHemicals), which aims at improving protection of human health and the environment from the risks caused by chemicals while promoting alternative methods ${ }^{24}$. Several Mn-(hyper)accumulating species have demonstrated their value in post-mining phytoremediation in New Caledonia ${ }^{25-27}$. These include three endemic species of Grevillea (Proteaeae); G. exul (subspecies exul and rubiginosa), G. gillivrayi, and G. meisneri. Like the endemic $\mathrm{Ni}$-hyperaccumulating species, these Mn-(hyper)accumulating trees are highly adapted to the local climatic and edaphic constraints of mining sites ${ }^{28-34}$. These pioneer trees have been introduced with success on degraded sites characterized by open environments, frequent water stress, and poor soil ${ }^{10}$. With their substantial biomass and extensive root systems, these trees can effectively revegetate mine sites. They also accumulate large quantities of $\mathrm{Mn}$, making them suited for applications in green chemistry. In 'normal' plants, foliar Mn concentration is around 50-800 $\mu \mathrm{g} \mathrm{g} \mathrm{g}^{-1}$ dry wet (based on crop studies). In other species classed as Mn-accumulators, foliar Mn concentrations range from 3000 to $10,000 \mu \mathrm{g} \mathrm{g}^{-128,30,35}$. In contrast, foliar Mn concentrations in Mn-hyperaccumulating species such as Grevillea meisneri can exceed $10,000 \mu \mathrm{g} \mathrm{g}^{-17,30,36}$. Their Mn-rich biomass is easily valorized by the use of powdered leaves as green and highly efficient catalysts in organic chemistry ${ }^{10,13,14,37}$.

New Caledonia hosts $11 \mathrm{Mn}$-hyperaccumulators and $24 \mathrm{Mn}$-accumulators recorded so far ${ }^{7,38}$. However, a recent screening of herbarium samples in New Caledonia using a portable XRF instrument has revealed the existence of numerous new hyperaccumulators. Their number on the island stands now at about 196, and additional hyperaccumulating species doubtless remain to be discovered ${ }^{8,9}$. Apart from New Caledonia, other Mn-hyperaccumulating plant species are known from Australia ${ }^{39,40}, \operatorname{Japan}^{41}$, China $^{42,43}$ and Malaysia ${ }^{44}$.

$\mathrm{Mn}$ is required by most organisms. In plants, its main role is as part of the Oxygen-Evolving Complex (OEC), co-factor of the Photosystem II (PSII) which performs the photo-oxidation of water during photosynthesis ${ }^{45-47}$. $\mathrm{Mn}$ plays also a main role in the activation of various enzymes in plants and as cofactors of enzymes, such as Mnsuperoxide dismutase (Mn-SOD), Mn-catalase, pyruvate carboxylase and phospho-enolpyruvate carboxykinase ${ }^{48}$. In addition, $\mathrm{Mn}$ is involved in the biosynthesis of chlorophyll. Through its role in the activation of several enzymes in the tricarboxylic acid cycle in the shikimic acid pathway, Mn also plays a role in the biosynthesis of aromatic amino acids and of various secondary products, such as lignin and flavonoids ${ }^{49}$.

Some soils are $\mathrm{Mn}$-deficient ${ }^{50}$ and $\mathrm{Mn}$-deficiency strongly affects photosynthesis ${ }^{51}$. In contrast, in some soils $\mathrm{Mn}$ reaches levels that are toxic for many plants ${ }^{52}$. Excess of $\mathrm{Mn}$ is particularly damaging for the photosynthetic apparatus ${ }^{53}$ but can also induce oxidative stress by the formation of reactive oxygen species ${ }^{54}$.

Adapting to such variation may require fine regulation of $\mathrm{Mn}$ assimilation and transport mechanisms ${ }^{55,56}$. Some plants are able to grow in soils in which other plants suffer Mn toxicity. Two mechanisms can account for such resistance: avoidance and tolerance ${ }^{57}$. One proposed mechanism of tolerance, which means the ability to tolerate high $\mathrm{Mn}$ concentrations in tissues, involves an efficient transport and sequestration of $\mathrm{Mn}$ in tissues where it does not interfere with metabolic activities. Thus, much attention has been devoted to studying the tissue microdistribution of metal elements in plants that hyperaccumulate them ${ }^{55}$.

Most previous studies on metal hyperaccumulators have focused on the distribution of metals within leaves, using various in vivo microprobe localization techniques. Pioneer studies conducted on Ni, $\mathrm{Zn}$ and Cd concluded that the highest foliar concentrations of these metals occurred in non-photosynthetic tissues ${ }^{58-64}$.

In contrast, the first investigation of a Mn-hyperaccumulating species by microprobe techniques, conducted on Gossia bidwillii (Benth.) N. Snow \& Guymer (Myrtaceae), revealed an unusual sequestration pattern, with Mn being mostly concentrated in the palisade mesophyll cells ${ }^{39}$. Subsequent studies of species in several families demonstrated three different patterns of Mn sequestration, with higher concentrations in dermal layers ${ }^{65-69}$ or in the palisade mesophyll ${ }^{70-74}$, or with Mn homogeneously distributed throughout the leaf cells ${ }^{68}$. Up to now, such variability in the foliar distribution of metals has been reported only in Mn-hyperaccumulators.

The Eco-Mn catalysts derived from the leaves of endemic New Caledonian Mn-(hyper)accumulators-three of four Grevillea taxa, including G. meisneri, as well as Garcinia amplexicaulis-exhibit a remarkable feature: the presence of mixed $\mathrm{Ca}-\mathrm{Mn}$ oxides, $\mathrm{Ca}_{2} \mathrm{Mn}_{3} \mathrm{O}_{8}$ and $\mathrm{CaMnO}_{3}{ }^{27,75}$. These Eco-CaMnO${ }_{\mathrm{x}}$ catalysts have distinct catalytic behavior making them suited for several novel applications ${ }^{75}$. Synthesis of these mixed oxides is difficult to achieve under laboratory (and industrial) condition $s^{76}$, and its presence in the ecocatalysts derived from the leaves of these plants is a significant discovery. The formation of these oxides may be inherently dependent on the physiology of these plants, but mechanisms are unknown. Describing the patterns of distributions of different 
metal elements in tissues of living hyperaccumulator plants may provide clues to understanding the interactions between them in the preparation of ecocatalysts.

Only one species of Grevillea, G. exul, has previously been studied by in vivo microprobe methodologies ${ }^{68,77-79}$. The first aim of the present study was to characterize the fine-scale tissue distribution of Mn in Grevillea meisneri, the only New Caledonian Mn-hyperaccumulator of the genus. The second objective was to determine whether the distributions of different metal elements are correlated (positively or negatively) with one another. We were particularly interested in the co-distribution patterns of $\mathrm{Mn}$ and $\mathrm{Ca}$, in the hope of obtaining clues about the mechanisms leading to the formation of mixed $\mathrm{Mn}$-Ca oxides in the ecocatalysts prepared from Mn-(hyper) accumulators. Although such mixed oxides are present in ecocatalysts prepared from prepared from different Grevillea species and Garcinia amplexicaulis ${ }^{27}$, we focused on Grevillea meisneri, as its performance shows the greatest potential for use in revegetation and in supplying biomass for production of ecocatalysts. A subsidiary objective of the study was to determine whether transplantation of nursery-grown G. meisneri seedlings into contaminated mining sites is an effective seeding strategy for revegetation efforts.

\section{Material and methods}

Study site. The study was conducted in degraded mining sites in 'Creek à Paul' valley near Tiébaghi $\left(20^{\circ} 29^{\prime} 35.03^{\prime \prime} \mathrm{S}, 164^{\circ} 12^{\prime} 22.76^{\prime \prime} \mathrm{E}\right)$, New Caledonia. Prior to mining operations, the valley's soils were brown hypermagnesian soils, classified as Magnesic Cambisols ${ }^{80}$. Derived from ultramafic rocks, these soils are characterized by low concentrations of essential elements, particularly P, high concentrations of heavy metals such as $\mathrm{Ni}, \mathrm{Mn}, \mathrm{Co}$, and $\mathrm{Cr}$, and a high ratio of exchangeable $\mathrm{Mg} / \mathrm{Ca}^{81}$. During mining operations, topsoil was removed, along with most of the organic matter and mineral nutrients, leaving behind a gravelly substrate composed of mining residues rich in transition metals, including $\mathrm{Ni}, \mathrm{Mn}$, and two highly toxic elements, $\mathrm{Cr}$ and Co. Concentrations of nutrient elements $(\mathrm{Ca}, \mathrm{K}$, and especially $\mathrm{P})$ are even lower than in the undisturbed soil prior to mining, whereas $\mathrm{Mg}$ can reach toxic levels. Organic matter is present in very small quantities ${ }^{26,82}$, and soils developing in this substrate are sterile and $\mathrm{N}$-deficient. Along with these highly constraining chemical properties, post-mining soils have been compacted by heavy machinery and present physical properties inimical to plant growth. Furthermore, in this seasonally dry climate, the open conditions are unsuitable for the establishment of forest species. All these conditions combine to make spontaneous revegetalisation very difficult, if not impossible ${ }^{31,82}$. Soils composition on the mining sites in 'Creek à Paul' are given in Table S1.

Study species: Grevillea meisneri. Endemic to New Caledonia ${ }^{83}$, G. meisneri grows only on the northwestern coast of the 'Grande Terre', on 'maquis' of variable density, preferentially on brown hypermagnesian soils under $650 \mathrm{~m}$ altitude ${ }^{84}$. Grevillea meisneri is the only Mn-hyperaccumulator among the Grevillea species endemic to New Caledonia ${ }^{7}$. This species was chosen for restoration efforts because of its adaptations to the site's harsh climatic and edaphic constraints. Observations of G. meisneri in its natural habitats indicated a good ability to establish.

Grevillea meisneri is a shrubby species that can reach up to $7 \mathrm{~m}$ height (Fig. 1a). Its tortuous branches are glabrous, rubiginous when young, and the wood is ash grey. The leaves are simple, coriaceous, lanceolate to elliptic, $35-140 \mathrm{~mm}$ long $\times 6-70 \mathrm{~mm}$ wide, petiolate. The adaxial surface (hereinafter referred to as 'upper epidermis') is glabrous and shiny light-green, whereas the abaxial surface (hereinafter referred to as 'lower epidermis') is hairy, matte and brownish, even silver-grey. The entire margin is entirely recurved underneath and the fine pinnate venation is barely visible. The brightly coloured carmine-red flowers are clustered into simple, cylindrical and pendulous racemes at the end of branches (Fig. 1b) ${ }^{85}$. Like other Proteaceae, G. meisneri is non-mycorrhizal but, like almost all other members of the family, develops cluster roots that improve nutrient uptake (Fig. 1c) ${ }^{86-89}$.

Plant materials. Restoration was carried out using plants of G. meisneri, among other (hyper)accumulators of metals (e.g. Ni, Zn). In 2014, 450 plants of G. meisneri were obtained from seeds collected in populations in the North Province of New Caledonia and grown for 18 months in pots in a nursery (see Supporting methods). Soil used in these pots was topsoil of brown hypermagnesian soils, collected in the valley of "Creek à Paul" prior to mining operations. The 18-month-old seedlings were then introduced into the post-mining site. Soil of each planting hole was amended with Yates nutricote 365, Superphosphate triple and a water-retention agent. The composition and quantity of fertilizers used for the plantation are given in Tables S2-S4. No further treatment was made post-plantation. Use of transplanted plants in restoration efforts was considered a challenge, because the site's edaphic and climatic conditions make establishment difficult, even for species such as G. meisneri that are adapted to local climate and to metal-rich soils. However, we considered that the performance of direct seeding would likely be even poorer.

For comparative purposes, we examined elemental composition in tissues of a Grevillea taxon that is neither a New Caledonian endemic nor a hyperaccumulator of $\mathrm{Mn}$. A commercially available ornamental variety known as "Grevillea 'rosa jenkinsii'”, derived from the Australian species Grevillea rosmarinifolia A. Cunn. Plants were grown in Montpellier under conventional conditions.

Harvesting of plant samples. Whole living plants of G. meisneri were collected in 2019. Dr C. Poullain undertook the formal identification of the plant material used in our study. Plant material collection and authorization for publication are according to the regulation of the North Province no 609011-40/2019/DEPART/JJC with effect since July 8th, 2019. This authorization is specific to this study and concerns the harvest of whole plants in the valley of "Creek à Paul" for analysis purpose of vegetal tissues. It was based on the Governmental authorization 036/2019, effective from June 6th, 2019 to June 5th, 2020. It follows the convention no 53 from October 18th, 2016 that stipulates New Caledonia authorizes the CNRS to have access to the entire private 

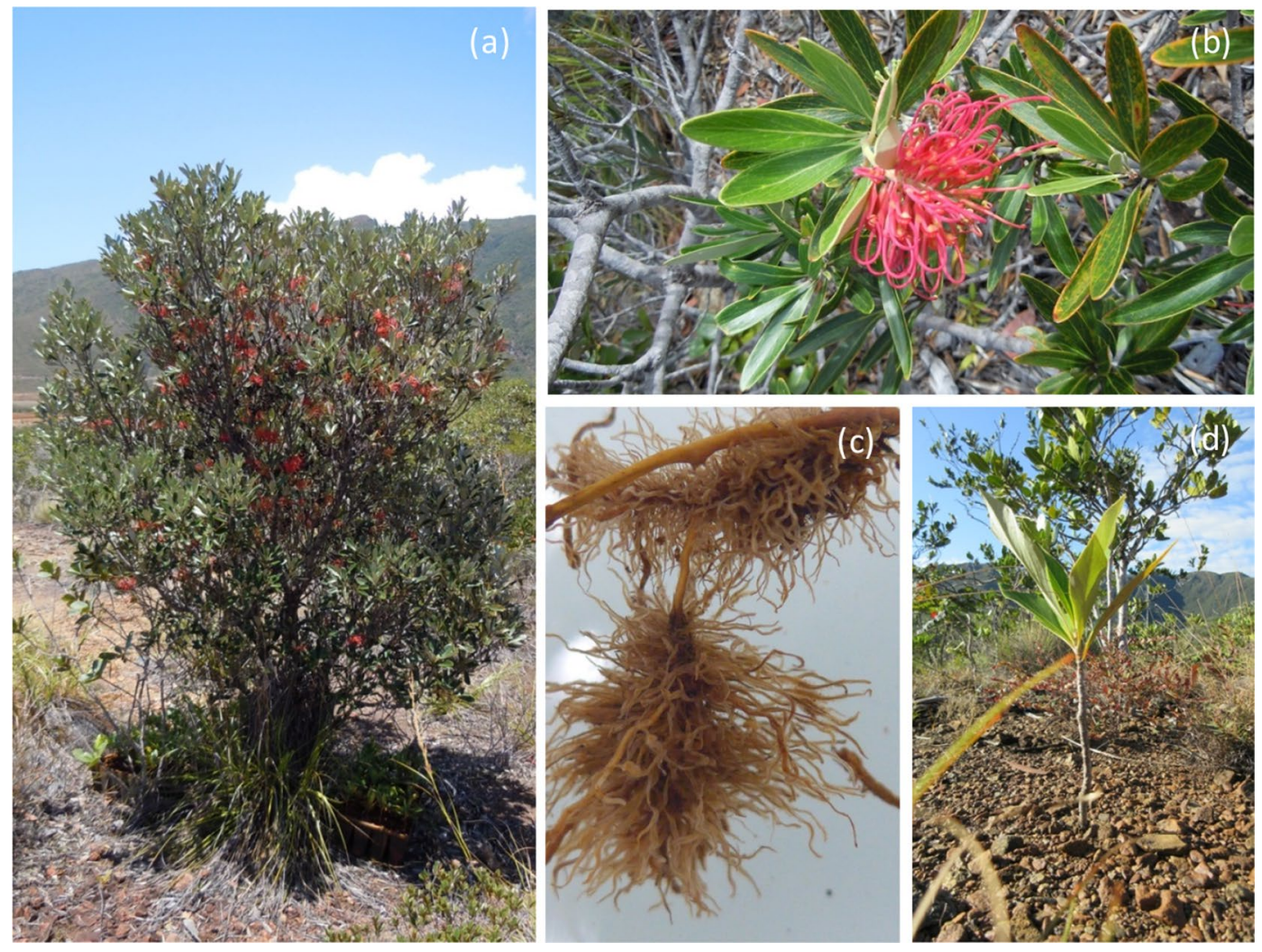

Figure 1. (a) Mature specimen of Grevillea meisneri; (b) Close-up of the inflorescence and the leaves of $G$. meisneri; (c) Close-up of the cluster roots of G. meisneri; (d) A young specimen of G. meisneri used for this study.

domain available of New Caledonia for the harvest of biological resources for purpose of scientific studies on vegetal species capable to hyperaccumulate heavy metals. The regulation on the access and collecting of biological, genetic and biochemical resources follows the Convention on Biological Diversity (CBD) and the Conservation of Migratory Species (CMS).

Transplanted plants, and spontaneously growing specimens of the same height and living in the same valley, were selected (Fig. 1d). Plants were collected with their soil and kept in pots for transportation to the laboratory, where samples were prepared within $24 \mathrm{~h}$ maximum post-harvest.

Measurements, shapes and colours of the different organs are based on the examination of herbarium material, fields, observations and material collected. The herbarium specimens of Grevillea were examined with the herbarium of Nouméa (NOU) (Herbarium acronyms follow Thiers 2020). The collections of G. meisneri from the north east of the main island were characterized by their architecture, the inflorescence axis, pedicels and perianth (Girardi plate 59 of the NOU herbarium). G. meisneri is easily distinguished by its vertically pendant inflorescences with a curved axis (rather than more or less horizontal inflorescences with a straight axis) and by its leaves less than $12 \mathrm{~cm}$ long on sterile axes ${ }^{83}$. A voucher specimen of G. meisneri from the site has been deposited in the herbarium of Nouméa (NOU) with the deposition number POU-0373.

MP-AES analyses. Tissue samples including leaves, stems, roots and cluster roots of G. meisneri were carefully washed with deionized water to remove soil particles and then oven-dried at $60^{\circ} \mathrm{C}$ overnight before being ground. Mineral composition was determined using an Agilent 4200 Microwave Plasma-Atomic Emission Spectrometer (MP-AES) coupled with an SPS4 autosampler. Approximatively $20 \mathrm{mg}$ of the ground biomass was digested in $6 \mathrm{~mL}$ of reversed aqua regia (1:2 hydrochloric acid (37\%): nitric acid (65\%)) under an Anton Paar Multiwave Go microwave-assisted digestion, with the following program: $20-164{ }^{\circ} \mathrm{C}$ in 20 min then 10 min isothermal at $164^{\circ} \mathrm{C}$. Samples were filtered and then diluted to $0.2 \mathrm{~g} \mathrm{~L}^{-1}$ in nitric acid (1\%). Three blanks were recorded for each step of the dilution procedure. Three analyses of the mineral composition were carried out for each sample to check repeatability of the measurement.

Ion chromatography. Ion chromatography analyses were carried out with a Metrohm 882 Compact IC instrument equipped with chemical (Metrohm suppressor MSM II for chemical) and sequential (Metrohm $\mathrm{CO}_{2}$ suppressor MCS) suppression modules, and a conductivity detector. Separations were performed on a Metrosep A Supp 16-250/4.0 column associated with a guard column kept at $55{ }^{\circ} \mathrm{C}$. The mobile phase consisted of a mixture of $7.5 \mathrm{mM} \mathrm{Na}_{2} \mathrm{CO}_{3}$ and $0.75 \mathrm{mM} \mathrm{NaOH}$ in ultrapure water. The flow rate was $0.8 \mathrm{~mL} \mathrm{~min}^{-1}$. Standard 
solutions were prepared from a commercial multi-element standard solution of $1000 \mu \mathrm{g} \mathrm{mL} \mathrm{mL}^{-1}$ of F $\mathrm{Cl}^{-}, \mathrm{Br}^{-}$, $\mathrm{NO}_{3}{ }^{-}, \mathrm{PO}_{4}{ }^{-}$and $\mathrm{SO}_{4}{ }^{2-}$ and from $\mathrm{Na}_{2} \mathrm{C}_{2} \mathrm{O}_{4}$ and $\mathrm{C}_{4} \mathrm{H}_{4} \mathrm{O}_{5} \mathrm{Na}_{2}$. Analyses were carried out at Laboratoire de Chimie Physique et Microbiologie pour les Matériaux et l'Environnement (LCPME-Université de Lorraine, France). Two separate chromatography analyses were recorded for each sample.

The samples were prepared using fresh leaves that were ground in deionized water using a mortar and pestle. The homogenate was filtered and the filtrate was collected for analysis. The residue was then extracted with isopropanol in the same way. The resulting residue was then finally extracted with dichloromethane, following the same procedure. The three filtrates were collected and analyzed.

Light microscopy. Fresh samples of G. meisneri, including leaves, stems, roots and cluster roots, were collected in situ and immediately fixed in formalin (10\%) during $24 \mathrm{~h}$. Fixed tissues were then embedded in paraffin (Paraplast plus) using a SAKURA VIP 5 JR vacuum infiltration processor and a SAKURA TEC-5 embedding console. The samples were sectioned at $6 \mu \mathrm{m}$ thickness under a rotary microtome (Leica RM2245). After staining with carmine red/iodine green, the tissue samples were examined using a light microscope (Leica DM3000) equipped with a camera (Leica MC170 HD).

Sample preparation for $\mu$ XFM analyses. Leaves, stems, roots and cluster roots of living plants of $G$. meisneri were carefully washed with deionized water before being dried with absorbing paper. Samples were cut and fragments of about $1 \mathrm{~cm}$ long were immediately immersed in an embedding compound (Optimal Cutting Temperature OCT from VWR) and fast frozen in isopentane, as liquid cryogen, cooled by liquid nitrogen ${ }^{90}$. This cryofixation protocol ensured an extremely fast cooling of the samples, preventing ice crystal formation. Therefore, it limited damage to the cellular structures and preserved elemental distribution close to its natural state. Leaf samples were divided into mid-rib (central vein) and margin. For the roots, the primary root and cluster roots were sampled. The samples were transported from New Caledonia in a cryogenic container, kept at $-80^{\circ} \mathrm{C}$ using dry ice, to SOLEIL Synchrotron (Saint-Aubin) for analysis and kept in a freezer at $-80{ }^{\circ} \mathrm{C}$ before cryo-sectioning.

Transverse sections of frozen-hydrated tissues were cut at a thickness of $20 \mu \mathrm{m}$ using a cryo-microtome (Thermo Fisher Scientific). The cryo-chamber was kept at $-20^{\circ} \mathrm{C}$. The thin sections were placed between two Ultralene films (SPEX SamplePrep) in a copper sample holder.

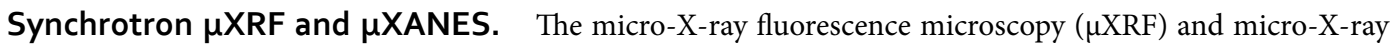
Absorption Near Edge Structure ( $\mu$ XANES) analyses were carried out at the LUCIA beamline ${ }^{91}$ at SOLEIL Synchrotron. The X-ray beam was monochromatized at $6.65 \mathrm{keV}$ using a fixed exit double-crystal Si (111) monochromator, calibrated to $6539 \mathrm{eV}$ at the first inflection point of a thin elemental Mn foil XANES spectrum. The beam was focused to $3.6 \times 2.9(\mathrm{v} \times \mathrm{h}) \mu \mathrm{m}^{2}$ by means of a Kirkpatrick-Baez mirrors arrangement. The XRF signal was collected using a mono-element $\left(60 \mathrm{~mm}^{2}\right)$ Bruker silicon drift diode detector. Samples were transferred into the experimental chamber under liquid nitrogen vapor to maintain the cold chain. Samples were scanned under cryogenic conditions using a liquid nitrogen cryostat, and under vacuum in order to limit absorption and scattering by air. $\mu$ XRF maps were collected in continuous Fly-scan mode with a pixel size of $3 \times 3 \mu \mathrm{m}^{2}$ and an integration time of $200 \mathrm{~ms}$ per pixel for high spatial resolution maps. The selection of appropriate areas for high spatial resolution maps was based on low spatial resolution maps (pixel size between $10 \times 10$ and $100 \times 100 \mu \mathrm{m}^{2}$ and with an integration time of $50 \mathrm{~ms}$ per pixel). $\mu$ XANES spectra were collected on points of interest, based on the foliar $\mu$ XRF elemental maps. Continuous FlyScan XANES were recorded in fluorescence mode in the 6475-6700 eV energy range with an equivalent energy step of $0.2 \mathrm{eV}$ and an integration time of $100 \mathrm{~ms}$ per point. One to four spectra were collected on the same points of interests, as a function of the Mn concentrations.

Data processing and statistics. The count number for the XRF signal was normalized by the count number of the incoming beam signal and corrected by the XRF detector dead time. To optimize the discrimination of the various XRF line contributions, the XRF signal of each element was extracted by batch fitting the XRF spectrum in each pixel of the map using the PyMCA software ${ }^{92}$. The XANES spectra were normalized and background-subtracted using Athena software ${ }^{93}$ and the repetitions merged.

Data transformation and statistical analyses. Regions of interest (ROIs) were selected from the maps using the ROI tool in the Fiji software ${ }^{94}$ according to the tissues of the organs. The different types of tissues identified are reported in Table 1 . Average fluorescence intensities of each element among the different tissues were obtained from the selected ROIs.

Correlations between $\mathrm{Mn}, \mathrm{Ca}, \mathrm{Cl}, \mathrm{K}, \mathrm{Mg}, \mathrm{P}$ and $\mathrm{S}$ concentrations were estimated by extracting fluorescence intensity pixel by pixel for each element from the selected ROIs. Pearson correlation coefficients between the different elements, and their P-values, were calculated using R (R Core Team). Holm's correction for multiple comparisons tests was applied.

PCA analyses. Principal component analyses (PCA) were performed for each element on judiciously chosen tissues of the different organs of G. meisneri to investigate co-localisation of the elements, with a particular focus on Mn. Data used for PCA analyses were collected from the tissues of each organ in which Mn was most highly concentrated, i.e., the dermal layers for the leaf, the cortex for the stem, the cortex of the primary root, and the pericycle-endodermis layers and phloem of the parent cluster root. Unscramble (Camo Analytics) was used to perform the PCA. 


\begin{tabular}{|l|l|}
\hline Organ & Identified tissues \\
\hline Leaf margin & Cuticle, upper epidermis, palisade mesophyll, spongy mesophyll, lower epidermis \\
\hline Leaf mid-rib & Upper epidermis, palisade mesophyll, vascular bundles, spongy mesophyll, lower epidermis \\
\hline Stem & Periderm, cortex, phloem, xylem, pith \\
\hline Primary root & Periderm, cortex, phloem, xylem \\
\hline Parent root and cluster rootlets & Cluster rootlets, epidermis, cortex, periderm and endoderm layers, phloem, xylem \\
\hline
\end{tabular}

Table 1. Tissues identified in the different organs of Grevillea meisneri. Tissues were described from the outside to the inside of the corresponding organ.

\begin{tabular}{|l|l|l|l|l|l|l|}
\hline \multirow{4}{*}{ Tissues } & \multirow{5}{|l|}{ Composition $[$ wt $\%( \pm$ S.E. $)]$} \\
\cline { 2 - 7 } & Group & Mn & Ca & K & Mg & Na \\
\hline \multirow{2}{*}{ Leaves } & $\mathrm{T}(7)$ & $0.31( \pm 0.09)$ & $0.59( \pm 0.07)$ & $0.30( \pm 0.07)$ & $0.23( \pm 0.06)$ & $0.12( \pm 0.03)$ \\
\cline { 2 - 7 } & $\mathrm{S}(8)$ & $0.39( \pm 0.21)$ & $0.55( \pm 0.16)$ & $0.29( \pm 0.11)$ & $0.11( \pm 0.04)$ & $0.18( \pm 0.10)$ \\
\hline \multirow{3}{*}{ Stems } & $\mathrm{T}(4)$ & $0.14( \pm 0.05)$ & $0.63( \pm 0.19)$ & $0.35( \pm 0.12)$ & $0.13( \pm 0.06)$ & $0.09( \pm 0.04)$ \\
\cline { 2 - 7 } & $\mathrm{S}(2)$ & $0.22( \pm 0.08)$ & $0.50( \pm 0.04)$ & $0.10( \pm 0.08)$ & $0.17( \pm 0.04)$ & $0.15( \pm 0.02)$ \\
\hline \multirow{3}{*}{ Primary roots } & $\mathrm{T}(6)$ & $0.06( \pm 0.03)$ & $0.24( \pm 0.08)$ & $0.11( \pm 0.09)$ & $0.14( \pm 0.04)$ & $0.08( \pm 0.02)$ \\
\cline { 2 - 7 } & $\mathrm{S}(6)$ & $0.20( \pm 0.10)$ & $0.74( \pm 0.25)$ & $0.20( \pm 0.11)$ & $0.23( \pm 0.20)$ & $0.16( \pm 0.06)$ \\
\hline \multirow{2}{*}{ Parent cluster roots } & $\mathrm{T}(6)$ & $0.12( \pm 0.03)$ & $1.00( \pm 0.28)$ & $0.31( \pm 0.18)$ & $0.29( \pm 0.06)$ & $0.43( \pm 0.09)$ \\
\cline { 2 - 7 } & $\mathrm{S}(2)$ & $0.21( \pm 0.11)$ & $0.49( \pm 0.02)$ & $0.11( \pm 0.08)$ & $0.44( \pm 0.36)$ & $0.22( \pm 0.01)$ \\
\hline
\end{tabular}

Table 2. Elemental composition in tissues of plants of Grevillea meisneri that had been grown in a nursery and then transplanted $(\mathrm{T})$ and plants that had grown spontaneously $(\mathrm{S})$ in the rehabilitation site, determined by MP-AES analyses (mean \pm standard error). Numbers in brackets denote the separate samples analyzed. Ni was also analyzed but not detected.

\section{Results}

Bulk elemental composition in tissues of Grevillea meisneri. The elemental composition of tissues of G. meisneri is shown in Table 2. Calcium was the major mineral element in all plant tissues analyzed, with a range of concentrations of $0.5-0.8 \mathrm{wt} \%$ (DW). Manganese presented concentrations similar to or even higher than those of macronutrient elements such as $\mathrm{K}$ and $\mathrm{Mg}$ in each tissue and especially in leaves, with up to 0.4 wt $\%$. No significant differences in concentrations of Mn were observed between nursery-grown plants that had been transplanted and those that had grown spontaneously in the rehabilitation site. Although soils of the site are enriched in $\mathrm{Ni}$, this element was not detected in any part of G. meisneri plants. As a comparison, the cultivated variety known as "Grevillea 'rosa jenkinsii' ", derived from the Australian species Grevillea rosmarinifolia A. Cunn., presented quite similar foliar composition in macronutrient, such as $\mathrm{K}, \mathrm{Mg}, \mathrm{Na} .$. but higher Ca concentrations than in G. meisneri. The very low concentrations of $\mathrm{Mn}$ in their leaves, less than $0.1 \mathrm{wt} \%$, testified Grevillea 'rosa jenkinsii' is not an accumulator of Mn compared to New Caledonian Grevillea species.

Concentrations of P and S in leaves were determined by ICP-MS (Table S6). The concentration of P was very low, even lower than the concentration of S, as in other native New Caledonian Grevillea spp. Conversely, Grevillea 'rosa jenkinsii' presented a much higher P concentration (Table S6).

Ion chromatography of Grevillea meisneri leaves. Chemical composition of the leaves of G. meisneri was further analyzed by ion chromatography (Table S7). The presence of carboxylates was investigated and analyses revealed high contents of malate and oxalate, while citrate could not be detected. Two other anions were abundant, sulfate and phosphate. Concentration of phosphate was about four times higher than that of sulfate. This high phosphate content is surprising for a plant belonging to the family Proteaceae, growing in such phosphorus-depleted soil.

Anatomical features of Grevillea meisneri leaves, stems and roots. Light microscopic analysis was conducted on leaves, stems and roots of G. meisneri. The different types of tissues identified in the various organs of G. meisneri are reported in Table 1. Using the criteria defined in our methods (see Supporting methods $)^{95}$, no differences were observed in anatomical features of plants that had been transplanted and those that had grown spontaneously in the rehabilitation site.

Light microscopy images of leaves showed a thick cuticular layer, as expected for a xerophytic species (Fig. 2a,b). The upper epidermis is composed of a single layer of large cells, twice as large as those of the lower epidermis. The palisade mesophyll consists of thin, elongated cells aligned in a single layer, as was observed using PIXE/EDS and SEM/EDS for Grevillea exul ${ }^{68}$. The spongy mesophyll accounted for more than half of the total thickness of the mesophyll. The dermal layers accounted for about $25 \%$ of the total leaf volume. 


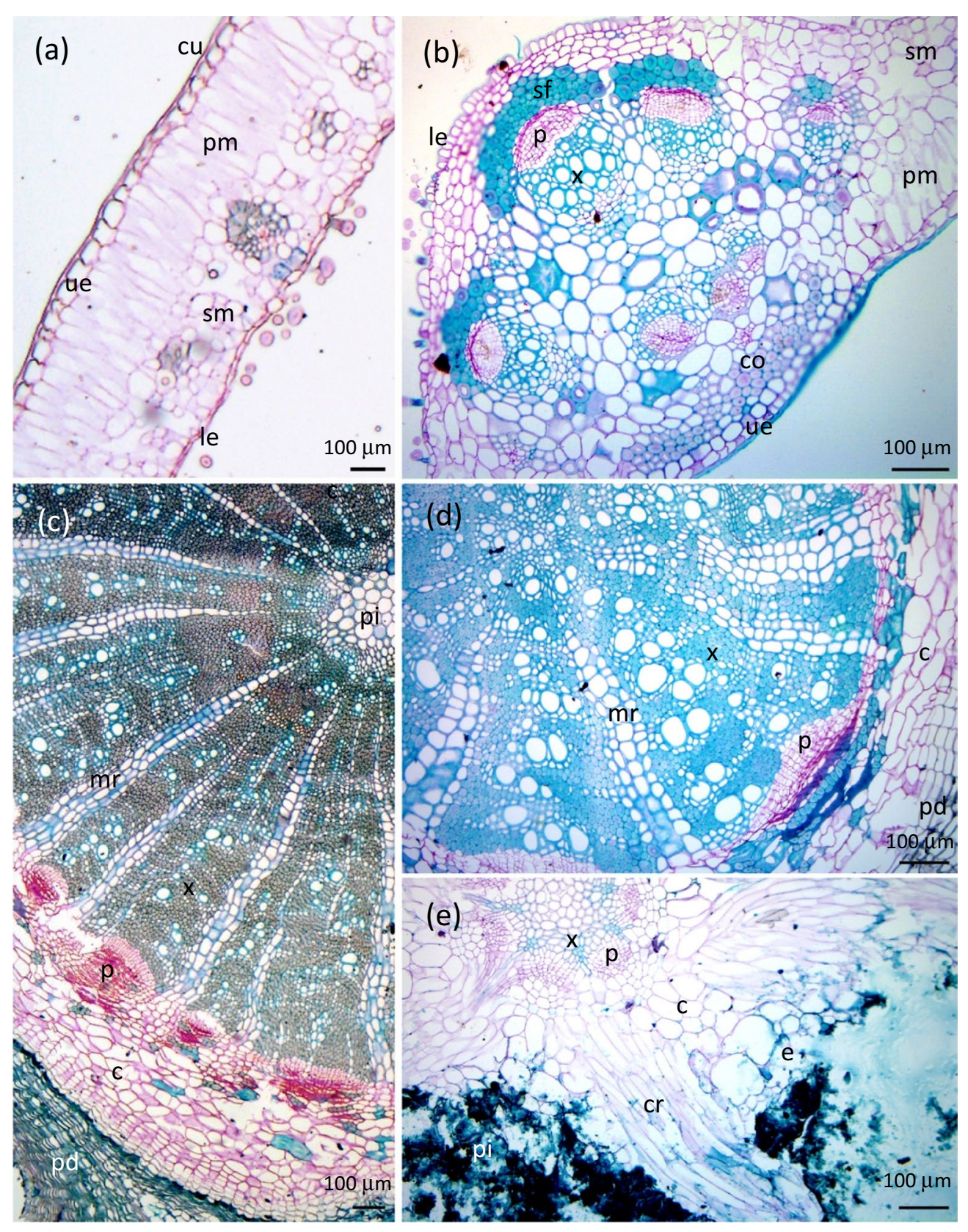

Figure 2. Light microscopy images of Grevillea meisneri anatomical structures. (a) Margin of a leaf; (b) midrib of a leaf; (c) stem; (d) primary root; (e) secondary root surrounded by the rootlets of a cluster. $c$ cortex, $c o$ collenchyma, $c r$ cluster rootlet, $c u$ cuticle, $e$ epidermis, le lower epidermis, $m r$ medullary ray, $p$ phloem, $p i$ pith, $p m$ palisade mesophyll, $p d$ periderm, $s f$ sclerenchyma fiber, $s m$ spongy mesophyll, ue upper epidermis, $x$ xylem.

The stems exhibited a typical secondary growth structure with a small cortex, a large stele with well-defined vascular bundles, and a periderm, which comprises the outermost tissue of the stem (Fig. 2c). Likewise, the primary roots had a typical secondary growth structure (Fig. 2d). Samples of cluster roots were cut so as to obtain a cross-section of the parent root, so only a tangential section of cluster rootlets stemming from the parent root could be mapped (Fig. 2e). Light microscopy images of cluster roots clearly revealed the primary structure of the parent root, with a wide parenchymatous cortex split by cluster rootlets. The rootlets seemed to emerge from the parental pericycle, opposite the xylem poles, as first described by Purnell (1960) for the general structure of cluster roots ${ }^{86}$. The tangential section of the cluster rootlets gave little information concerning the anatomical structure of the rootlets.

Elemental distribution in leaves, stems and roots of Grevillea meisneri determined by $\mu \mathrm{XRF}$. Micro-X-ray fluorescence was performed on leaves, stems, roots and cluster roots of transplanted and spontaneously growing plants of G. meisneri and allowed elemental mapping of frozen hydrated tissues in a 

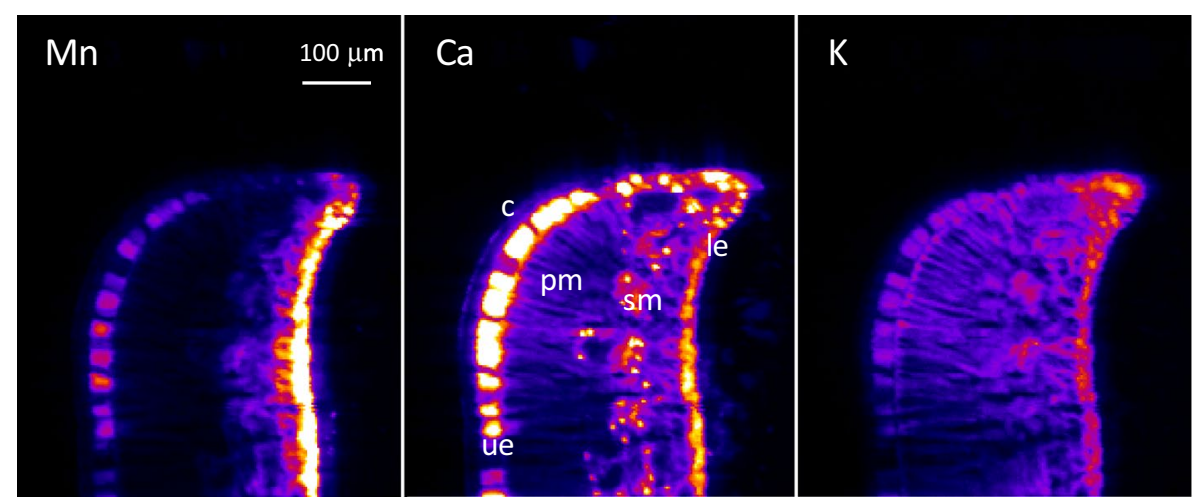

High concentrations

Figure 3. $\mu \mathrm{XRF}$ maps of $\mathrm{Mn}, \mathrm{Ca}$, and $\mathrm{K}$ for a cross-section of a frozen hydrated leaf margin of transplanted Grevillea meisneri. The pixel size is $3 \mu \mathrm{m}$. The intensity scales are different between elements. $c$ cuticle, le lower epidermis, $p m$ palisade mesophyll, sm spongy mesophyll, ue upper epidermis.

state as close as possible to the native state ${ }^{72}$. The $\mu$ XRF maps of $G$. meisneri leaves, stems and roots showed no differences in elemental distributions between transplanted plants and those growing spontaneously in the site. $\mu$ XRF maps obtained for G. meisneri spontaneously growing in the site are given in Supporting Information. The brightness of each elemental $\mu \mathrm{XRF}$ map was scaled for an optimum contrast, so the pixel intensities did not represent relative differences in concentration between different elements, but represented differences in concentration for a given element in the different maps. $\mu$ XRF maps of $K$ were used as a control since the presence of cellular $\mathrm{K}$ in all samples indicated the retention of cell contents, thus showing the efficiency of the preparation.

$\mu \mathrm{XRF}$ maps of the leaves revealed that Mn was sequestered in the epidermis, mostly in the lower epidermis, and was found, in lower concentrations, in vascular tissues and the spongy mesophyll (Fig. 3 and Figs. S1-S4). Ca was also mostly localized in the dermal layers, with a higher concentration in the upper epidermis. High-intensity Ca spots throughout the spongy mesophyll suggested the presence of calcium oxalate crystals. Magnesium was mostly localized in the dermal tissues. Other nutrient elements $(\mathrm{K}, \mathrm{Cl}, \mathrm{S}$ and $\mathrm{P})$ were globally distributed throughout the leaves. However, P showed a higher concentration in the vascular tissues, whereas $\mathrm{S}$ was mostly in the mesophyll (Figs. S2 and S4).

$\mu \mathrm{XRF}$ maps of the stem showed that Mn was highly concentrated in the cortex, sixfold higher than in other parts of the stem, and was also found in the vascular tissues, particularly in the phloem (Fig. 4 and Figs. S5, S6). Ca was also localized in the cortex and highly concentrated in cells aligned in axial rays around the xylem. A similar Ca enrichment in medullary rays was previously reported in the Ni-hyperaccumulator Rinorea cf. javanica ${ }^{96}$. A similar distribution was observed for $\mathrm{S}$ and $\mathrm{Mg}$. K was homogeneously distributed through the stem, with a slightly higher concentration in the phloem, whereas $\mathrm{P}$ attained its highest concentrations in the xylem. $\mathrm{Cl}$ was mostly in the cortex as well as in the inner periderm.

$\mu \mathrm{XRF}$ maps of the primary roots showed that Mn was mainly localised in the cortex and the phloem, the cortex showing the highest Mn concentration (Fig. 5 and Figs. S7, S8). In the cortex, Mn was mostly localized in the apoplastic spaces. Similarly to $\mathrm{Mn}$, Ca was located in the cortex and in the phloem, but with the highest concentration in the latter tissue. $\mathrm{Cl}$ was concentrated in the phloem and inner periderm. $\mathrm{K}$ distribution mirrored that of $\mathrm{Cl}$ with a strong enrichment in the phloem. $\mathrm{P}$ was concentrated in the vascular tissues of the roots.

$\mu \mathrm{XRF}$ maps of the cluster roots showed that Mn was mainly concentrated in the phloem and in the pericycle-endodermis layers of the parent cluster root (Fig. 6 and Figs. S9-S11). Mn was found in lower concentration in the cortex. Ca was distributed throughout the parent cluster root and the rootlet, principally in the pericycle-endodermis layers and phloem. $\mathrm{Cl}$ was concentrated in the cortex in the parent cluster roots, and $\mathrm{K}, \mathrm{Mg}$ and $\mathrm{S}$ were evenly distributed throughout the parent cluster roots, with a minor enrichment in the phloem. P was mainly localized in the phloem of the parent cluster roots.

Co-localization of elements. An example of the graphs depicting the correlation circles between the first two principal components of the PCA of the lower and upper epidermis of the leaf margin of G. meisneri was presented in Fig. S12. Interestingly, in each organ a strong positive correlation between Mn and Ca concentrations was observed $(P \leq 0.0001$, Table 3 and Table S8). Overall, no strong positive correlations across all tissues were found between $\mathrm{Mn}$ and any other physiological element. $\mathrm{Mn}$ and $\mathrm{Mg}$ were both concentrated in the upper epidermis of the leaf and in the cortex of the stem, and both $\mathrm{K}$ and $\mathrm{Cl}$ showed positive correlations with $\mathrm{Mn}$ in the phloem of the parent cluster root.

MXANES spectra. Based on the $\mu$ XRF elemental maps obtained for the leaves of transplanted G. meisneri, $\mu X A N E S$ spectra were collected on points of interest chosen for different concentrations in $\mathrm{Mn}$ and/or Ca, meaning lower epidermis (richer in $\mathrm{Mn}$ than in $\mathrm{Ca}$ ), upper epidermis (richer in Ca than in $\mathrm{Mn}$ ), spongy mesophyll, palisade mesophyll and vascular bundles (each ones with poor concentrations of Mn and Ca) (Fig. S13). The aim was to study the potential spatial heterogeneity for Mn speciation all along the epidermal layers and the mesophyll of G. meisneri' leaves. 

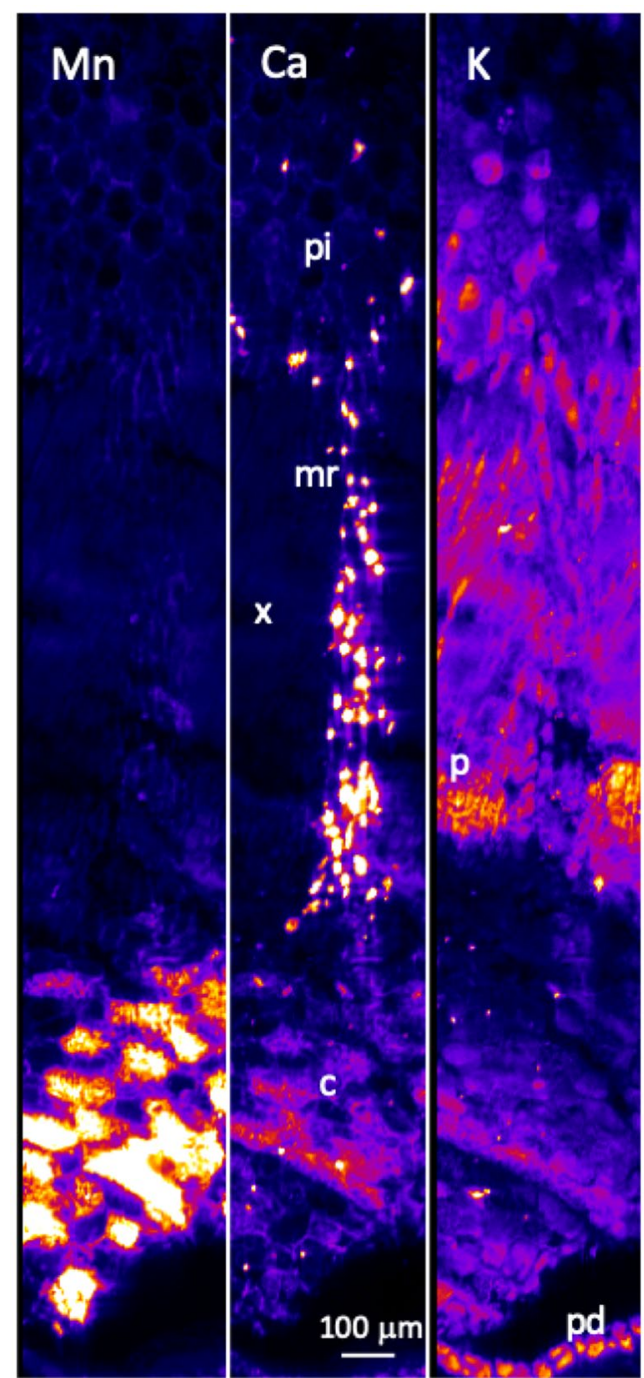

\section{High concentrations}

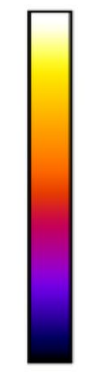

\section{Low concentrations}

Figure 4. $\mu \mathrm{XRF}$ maps of $\mathrm{Mn}, \mathrm{Ca}$ and $\mathrm{K} \mu \mathrm{XRF}$ for a cross-section of a frozen hydrated stem of transplanted Grevillea meisneri. The pixel size is $3 \mu \mathrm{m}$. The intensity scales are different between elements. $c$ cortex, $m r$ medullary ray, $p$ phloem, $p i$ pith, $p d$ periderm, $x$ xylem.

For every tissue, the normalized XANES spectra were strongly characteristic of $\mathrm{Mn}(\mathrm{II})$, by both edge energies and shapes of the spectra. The pre-edge peak at $6540 \mathrm{eV}$, the intense white-line peak at $6553 \mathrm{eV}$ and the spectral shape on the high-energy side of the white-line peak around $6566 \mathrm{eV}$ are indicative of an octahedral or pseudooctahedral coordinative environment around $\mathrm{Mn}(\mathrm{II})^{79,97}$. No differences were observed with the variation of concentration of $\mathrm{Mn}$, of $\mathrm{Ca}$ nor the ratio $\mathrm{Mn} / \mathrm{Ca}$.

\section{Discussion}

Micro-X-ray elemental mapping techniques give in situ information on the cellular distribution of elements within plant tissues, effectively immobilizing their metabolic processes to yield material whose state is as close as possible to the native state of the sample. It preserves not only the morphological structures of the sample but also the in vivo distribution and chemical form of the cellular elements. Indeed, the fast freezing of freshly excised small samples, as followed in this study, avoids the formation of ice crystals which would lead to artefacts, such as damage to cell structure, elemental redistribution or loss of cell solutes ${ }^{90,98}$. The use of Synchrotron radiation micro-X-Ray Fluorescence spectroscopy ( $\mu \mathrm{XRF}$ ) enabled mapping of $\mathrm{Mn}$ together with $\mathrm{Ca}, \mathrm{Cl}, \mathrm{K}, \mathrm{Mg}, \mathrm{P}$ and $\mathrm{S}$, in the different tissues of G. meisneri.

For both transplanted and spontaneously growing plants, evaluation of tissue-Mn in across all organs of $G$. meisneri showed that its leaves contain highest concentrations, as expected for a (hyper)accumulated metal. Even higher concentrations of Mn could have been expected in leaves, as a mean concentration of $0.7 \mathrm{wt} \%$ (and a maximum of $1.1 \mathrm{wt} \%$ ) was previously found in leaves of G. meisneri ${ }^{7}$. However, the lower values for Mn concentrations obtained in this study, which used young leaves, could be explained by the previously established relationship between leaf age and foliar concentration of $\mathrm{Mn}$, the oldest leaves having the highest Mn concentrations. 


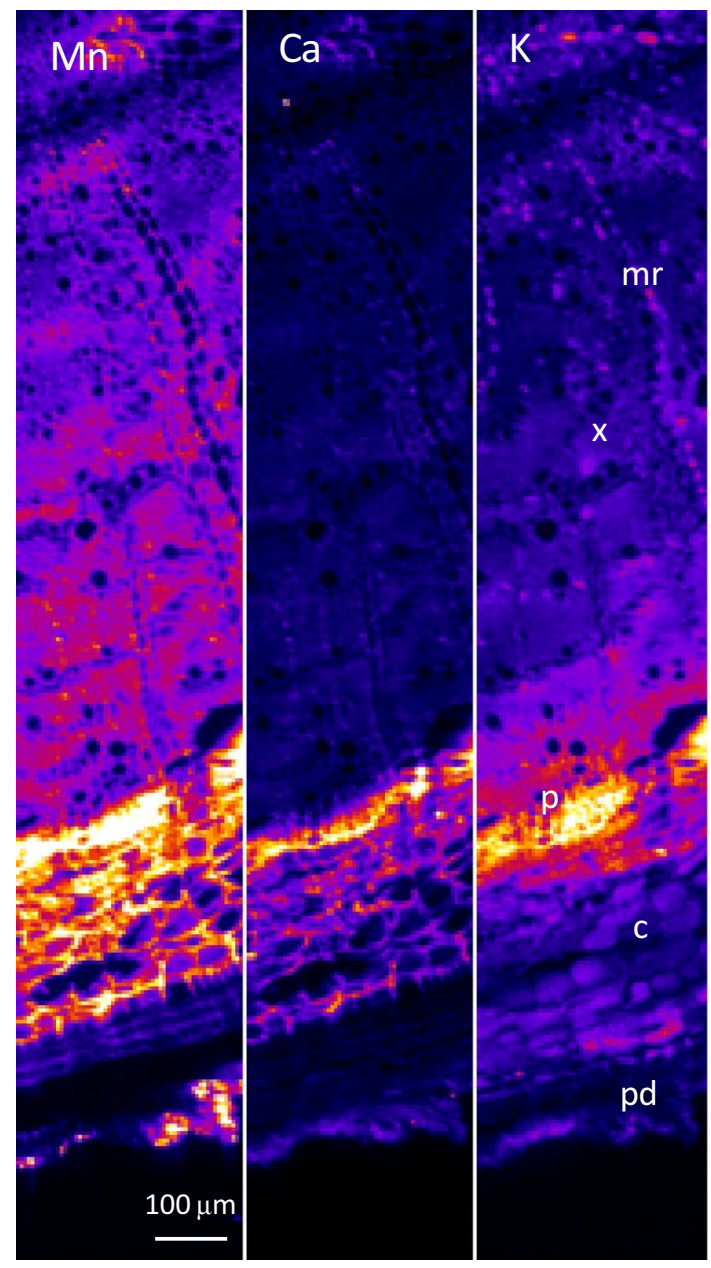

\section{High concentrations}

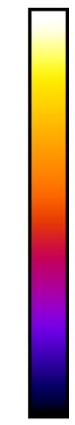

\section{Low concentrations}

Figure 5. $\mu \mathrm{XRF}$ maps of $\mathrm{Mn}, \mathrm{Ca}$ and $\mathrm{K}$ for a cross-section of a frozen hydrated primary root of transplanted Grevillea meisneri. The pixel size is $3 \mu \mathrm{m}$. The intensity scales are different between elements. $c$ cortex, $m r$ medullary ray, $p$ phloem, $p d$ periderm, $x$ xylem.
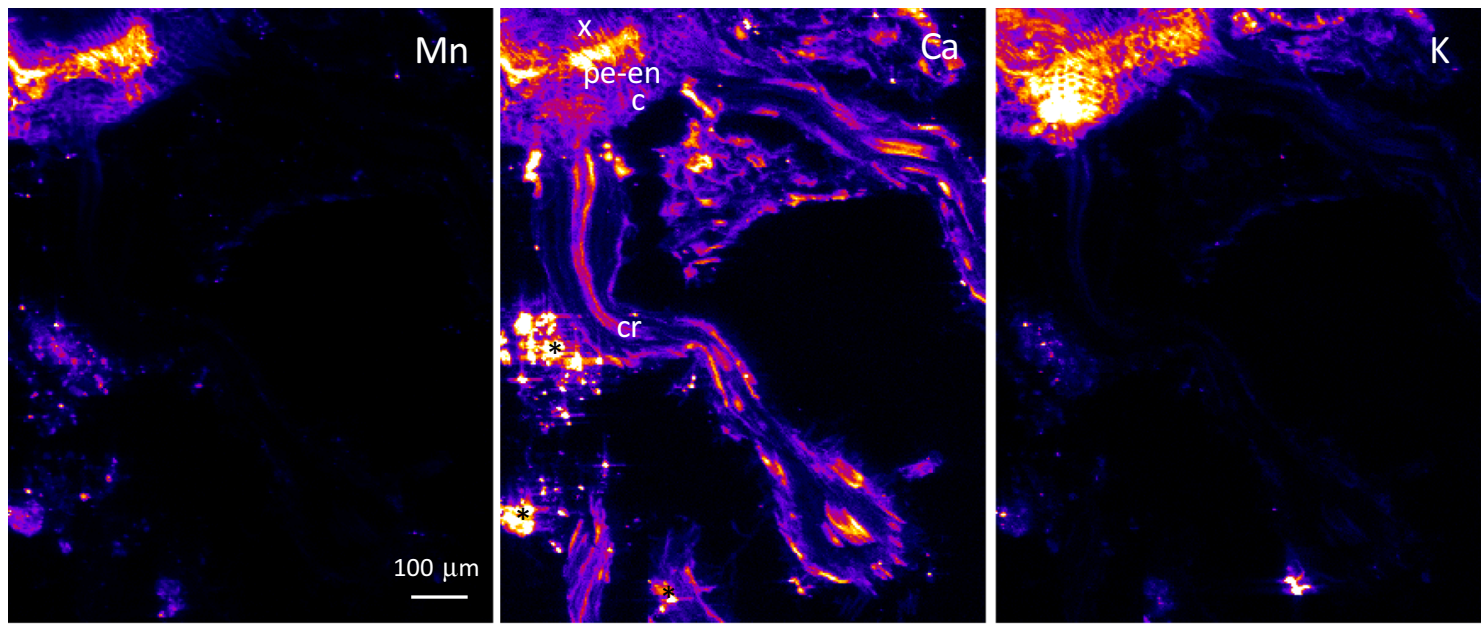

\section{Low concentrations}

High concentrations

Figure 6. $\mu \mathrm{XRF}$ maps of $\mathrm{Mn}, \mathrm{Ca}$ and $\mathrm{K}$ for a cross-section of frozen hydrated cluster root of transplanted Grevillea meisneri. The pixel size is $3 \mu \mathrm{m}$. The intensity scales are different between elements. $c$ cortex, $c r$ cluster rootlet, $p$ phloem, $p e-e n$, pericycle-endodermis, $x$ xylem. Asterisks indicate soil particles. 


\begin{tabular}{|l|l|l|l|l|l|l|l|}
\hline Organ & Tissue & $\mathbf{M n} / \mathbf{C a}$ & $\mathbf{M n} / \mathbf{C l}$ & $\mathbf{M n} / \mathbf{K}$ & $\mathbf{M n} / \mathbf{M g}$ & $\mathbf{M n} / \mathbf{P}$ & $\mathbf{M n} / \mathbf{S}$ \\
\hline \multirow{2}{*}{ Leaf margin } & ue & $\mathbf{0 . 6 8}$ & $\mathbf{0 . 5 3}$ & 0.40 & 0.47 & 0.40 & $\mathbf{0 . 5 1}$ \\
\cline { 2 - 8 } & le & $\mathbf{0 . 9 4}$ & 0.48 & 0.45 & 0.30 & 0.43 & 0.44 \\
\hline \multirow{2}{*}{ Leaf mid-rib } & ue & $\mathbf{0 . 9 8}$ & 0.28 & 0.45 & $\mathbf{0 . 7 3}$ & 0.39 & 0.45 \\
\cline { 2 - 8 } & le & $\mathbf{0 . 7 3}$ & 0.23 & 0.27 & 0.36 & 0.32 & 0.30 \\
\hline Stem & $\mathrm{c}$ & $\mathbf{0 . 6 0}$ & 0.11 & 0.34 & $\mathbf{0 . 5 6}$ & 0.47 & 0.41 \\
\hline Primary root & $\mathrm{c}$ & $\mathbf{0 . 8 9}$ & 0.48 & 0.38 & 0.28 & 0.26 & 0.12 \\
\hline \multirow{2}{*}{ Parent cluster Root } & pe-en & $\mathbf{0 . 8 4}$ & 0.43 & 0.49 & 0.45 & 0.46 & 0.45 \\
\cline { 2 - 8 } & $\mathrm{p}$ & $\mathbf{0 . 9 4}$ & $\mathbf{0 . 7 2}$ & $\mathbf{0 . 7 3}$ & 0.25 & $-0.11^{\#}$ & $0.04^{\# \#}$ \\
\hline
\end{tabular}

Table 3. Pearson correlation coefficients between $\mathrm{Mn}$ and other physiological elements among the main $\mathrm{Mn}$ sinks of the different organs of Grevillea meisneri (ue upper epidermis, le lower epidermis, $c$ cortex, pe-en pericycle-endodermis layers, $p$ phloem). P-values are all $\leq 0.0001$, except where otherwise indicated. Values of Pearson correlation coefficient higher than 0.5 are indicated in bold characters. ${ }^{\#} P$-value: 0.0007 . ${ }^{\#} P$-value: 0.17 .

Substantial concentrations of Mn were also found in roots. Interestingly, no Ni was detected using MP-AES in any part of the plant, although G. meisneri grew on Ni-enriched soil and was surrounded by Ni-hyperaccumulator species. Specific transporters of $\mathrm{Mn}^{2+}$, such as carboxylate complexes that are secreted by cluster roots of Proteaceae ${ }^{99}$, might explain this specific uptake mechanism towards Mn versus Ni. $\mu$ XANES spectra obtained in many points of every tissue of G. meisneri demonstrated the predominance of $\mathrm{Mn}$ (II) oxidation state, which was consistent with previous investigations on the speciation of $\mathrm{Mn}$ in plants ${ }^{46}$. Some studies have suggested

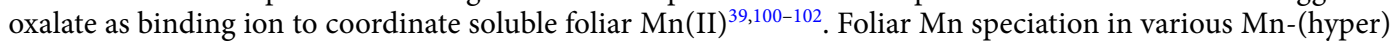
accumulating plants, including G. exul, was extensively studied by XANES and EXAFS by Fernando et al. ${ }^{79}$. It was demonstrated that citrate and malate were the most plausible counter-ions associated to Mn(II), with some evidence in favor of malate. By comparison with the data obtained by Fernando et al., the $\mu$ XANES spectra collected in the leaves of G. meisneri clearly supported O-donor ligands as counter-ions to Mn(II), and mostly citrate and malate. Similarly, $\mu$ XANES data alone cannot differentiate precisely which carboxylate is involved in the binding of $\mathrm{Mn}(\mathrm{II})$. Ion chromatography analyses of leaves of $G$. meisneri revealed high contents of malate and oxalate, while citrate could not be detected. These analyses supported that malate could be involved in the sequestration of $\mathrm{Mn}$ in leaves of $\mathrm{G}$. meisneri while high oxalate content could come from Ca-oxalate crystals observed in the leaf mesophyll. Crystalline Ca-oxalate had already been reported in many previously studied Mn-(hyper)accumulators ${ }^{73,103}$ as well as in Grevillea exul ssp rubiginosa seeds ${ }^{104}$. The accumulation of Ca in the leaves of $G$. meisneri in sufficient quantity to form calcium oxalate crystals could signify some adaptation of the plants for the uptake of large amounts of $\mathrm{Ca}$ from ultramafic soils characterized by particularly low exchangeable Ca content ${ }^{105}$.

In leaves of G. meisneri, Mn was mainly sequestered in the epidermal tissues. The foliar sequestration of metals, including $\mathrm{Mn}^{65-69}, \mathrm{Ni}^{59,61-64}, \mathrm{Zn}$ and $\mathrm{Cd}^{58,60}$, usually occurs in non-photosynthetic tissues, enabling avoidance of any damage to cell metabolic activities. Here, the asymmetrical accumulation of Mn in epidermal layers might act as a chemical defense strategy against herbivory. In favour of this hypothesis is the observation that the lower epidermis presented more enrichment in $\mathrm{Mn}$ than the upper one, similar to findings for other heavy metals in other accumulator plants ${ }^{60,61,106-108}$. Many insect herbivores prefer to feed on leaf undersides, where the cuticle is often less tough, and where the insects have a little bit of shade. Although Mn is considered less toxic to plants than other metals, its detoxification is needed for Mn-hyperaccumulators and their strategy relies on cell vacuolation for $\mathrm{Mn}$ sequestration in leaves ${ }^{60,73,109}$. Although the resolution of $\mu \mathrm{XRF}$ was not sufficient to discern subcellular elemental localizations, the shape of Mn distribution in the epidermal layers, and the wide vacuolar volumes of the large dermal cells compared to the thin cells of the palisade, strongly suggest a vacuolar sequestration, without excluding localization in cell walls.

In stems, the presence of $\mathrm{Mn}$ in the vascular tissues and in the cortex could be respectively explained by its transportation from root to shoot and from shoot to older leaves ${ }^{56}$, and by its sequestration. Both mechanisms could represent an adaptive strategy developed by G. meisneri facing excessive concentrations of Mn.

$\mathrm{Mn}$ distribution in the primary roots revealed the early uptake of Mn through the apoplastic pathway in the cortex, before entering the symplast in the endoderm, then reaching the phloem, but not the xylem. Similar distribution of Mn has also been observed in the roots of Gossia fragrantissima (Myrtaceae) ${ }^{110}$. Further investigations are needed to deepen our understanding of Mn transportation, its low mobility in the phloem sap ${ }^{111}$ and its transportation from root to shoot in the xylem ${ }^{112}$, mainly considering that these processes generally observed in plants are not entirely followed by some Australian Gossia Mn-hyperaccumulator species, G. grayi and G. shepherdii ${ }^{113}$.

Strong positive $\mathrm{Mn} / \mathrm{Ca}$ correlations were observed in every tissue of G. meisneri where Mn was the most concentrated. Such positive Mn/Ca correlations have also been found in the dermal layers of other Mn-hyperaccumulators, Garcinia amplexicaulis (Clusiaceae) ${ }^{73}$, Gossia grayi and G. shepherdii (Myrtaceae) ${ }^{74}$. The co-localization of $\mathrm{Ca}$ and $\mathrm{Mn}$ in the same tissues of $\mathrm{G}$. meisneri might in some way facilitate the formation of mixed $\mathrm{Ca}-\mathrm{Mn}$ oxides upon preparation of Eco-CaMnOx ecocatalysts from this plant. The original structure and reactivity of Eco-CaMnOx are inherently linked to the leaves from which they come from: this represents the peculiar vegetal footprint of ecocatalysts. It might also indicate shared transport systems that could facilitate the formation 
of mixed oxides as well. Interestingly, the distributions of these two metal elements are negatively correlated in the mesophyll of two other Mn-hyperaccumulating Gossia species, the main Mn sequestration site for these species $^{74}$. If co-localization of the two elements facilitates formation of the mixed Mn-Ca oxide, this would lead to the predictions that (i) mixed Mn-Ca oxides would be absent from, or present in much lower concentrations in, ecocatalysts prepared from these Gossia species; and (ii) there is no shared transport system for $\mathrm{Mn}$ and Ca in these Gossia species. Unfortunately, whether such oxides occur in ecocatalysts prepared from any Gossia species appears still to be unknown. Whether shared $\mathrm{Mn} / \mathrm{Ca}$ transport systems exist is not known for any Mnhyperaccumulator. $\mathrm{Mn}$ (II) is the predominant ionic form of $\mathrm{Mn}$ in plants and shares similar radius and chemical features (hardness according to HSAB theory) with $\mathrm{Ca}(\mathrm{II})^{114}$. This similarity could explain the positive $\mathrm{Mn} / \mathrm{Ca}$ correlation via a cooperative uptake and transportation pathway in G. meisneri ${ }^{115}$. Indeed, many transporters of $\mathrm{Ca}(\mathrm{II})$, such as some membrane $\mathrm{Ca}^{2+}$ channels, are reported to be permeable to $\mathrm{Mn}$ in Arabidopsis thaliana (Brassicaceae) and in Acanthopanax sciadophylloides (Araliaceae) ${ }^{116-120}$.

In efforts to revegetate metal-bearing mine waste sites, direct seeding is almost universally used as a seeding strategy. In fact, the review by Tordoff et al. mentions transplantation only once ${ }^{121}$. However, in reforestation efforts in a diversity of contexts, studies have shown transplanted plants to have higher establishment, survivorship and growth rates than plants from direct seeding ${ }^{122}$. We showed that even in the harsh climatic and edaphic conditions in a site degraded by open-cast mining, nursery-grown transplants of a metal-tolerant native plant established successfully, accumulated $\mathrm{Mn}$ as efficiently as plants growing naturally in the sites, and sequestered $\mathrm{Mn}$ within their tissues in the same way as naturally growing plants.

In metalliferous mine waste sites, transplanting should confer even greater advantages relative to direct seeding than in other environments. The harsh, extreme conditions should make seed survival and seedling establishment particularly difficult. Bypassing the vulnerable seed-to-seedling life-history transition by growing young seedlings in favourable nursery environments could greatly increase the survivorship and growth rate of transplanted seedlings in mine waste sites. As in other parts of the world where naturally metalliferous soils occur, New Caledonia has native metal-tolerant plants that are highly suitable for revegetation efforts. Because seed supply of these native plants is often highly limited, seeding strategies based on transplanted nursery-grown seedlings will be much more efficient than direct seeding, in which a large proportion of seeds and young seedlings die before establishment.

Bermúdez-Contreras et al. pointed out a potential limitation of transplantation as a seeding strategy ${ }^{123}$. Establishment and growth of the young plant may depend on below-ground interactions, for example, the early establishment of associations with the locally adapted soil microflora (mycorrhizal fungi, but also other soil fungi and bacteria). With direct seeding, the young plant can form these associations, and benefit from them, at the start of its life. In contrast, nursery-reared seedlings are usually grown in tubes containing some standard soil, not the native soil of the sites to be revegetated. Transplanted to these sites, they may suffer a deficit of, or a lag in, colonization by the native microbiota. We circumvented potential problems caused by such disruption of underground interactions by growing nursery-reared seedlings in native soil of the site before mining. The native soil introduced with the transplants could help inoculate the site after removal of its topsoil. Our results suggest that transplantation should be increasingly adopted as a seeding strategy in restoration efforts in degraded mining sites.

Received: 23 July 2021; Accepted: 29 November 2021

Published online: 10 December 2021

\section{References}

1. Baker, A. \& Brooks, R. Terrestrial higher plants which hyperaccumulate metallic elements, a review of their distribution, ecology and phytochemistry. Biorecovery 1, 81-126 (1989).

2. Reeves, R. D. et al. A global database for plants that hyperaccumulate metal and metalloid trace elements. New Phytol. 218, 407-411 (2018).

3. Reeves, R. D., Baker, A. J. M., Borhidi, A. \& Berazaín, R. Nickel-accumulating plants from the ancient serpentine soils of Cuba. New Phytol. 133, 217-224 (1996).

4. Reeves, R., Baker, A., Borhidi, A. \& Berazaín Iturralde, R. Nickel hyperaccumulation in the serpentine flora of Cuba. Ann. Bot. 83, 29-38 (1999).

5. Whiting, S. N. et al. Research priorities for conservation of metallophyte biodiversity and their potential for restoration and site remediation. Restor. Ecol. 12, 106-116 (2004).

6. Jaffré, T., Pillon, Y., Thomine, S. \& Merlot, S. The metal hyperaccumulators from New Caledonia can broaden our understanding of nickel accumulation in plants. Front. Plant Sci. 4, 279 (2013).

7. Losfeld, G. et al. Leaf-age and soil-plant relationships: Key factors for reporting trace-elements hyperaccumulation by plants and design applications. Environ. Sci. Pollut. Res. Int. 22, 5620-5632 (2015).

8. Gei, V. et al. Tools for the discovery of hyperaccumulator plant species and understanding their ecophysiology. In Agromining: Farming for metals: Extracting unconventional resources using plants (eds Van der Ent, A. et al.) 117-133 (Springer International Publishing, 2018). https://doi.org/10.1007/978-3-319-61899-9_7.

9. Gei, V. et al. A systematic assessment of the occurrence of trace element hyperaccumulation in the flora of New Caledonia. Bot. J. Linn. Soc. 194, 1-22 (2020).

10. Grison, C., Escande, V. \& Biton, J. Ecocatalysis: A New Integrated Approach to Scientific Ecology (Elsevier, 2015).

11. Grison, C. Special issue in environmental science and pollution research: Combining phytoextraction and ecocatalysis: an environmental, ecological, ethic and economic opportunity. Environ. Sci. Pollut. Res. 22, 5589-5698 (2015).

12. Grison, C., Escande, V. \& Olszewski, T. K. Ecocatalysis: A new approach toward bioeconomy, chapter 25. In Bioremediation and Bioeconomy (ed. Prasad, M. N. V.) 629-663 (Elsevier, 2016). https://doi.org/10.1016/B978-0-12-802830-8.00025-3.

13. Deyris, P.-A. \& Grison, C. Nature, ecology and chemistry: An unusual combination for a new green catalysis, ecocatalysis. Curr. Opin. Green Sustain. Chem. 10, 6-10 (2018). 
14. Grison, C. \& LockToyKi, Y. Ecocatalysis, a new vision of green and sustainable chemistry. Curr. Opin. Green Sustain. Chem. 29, $100461(2021)$.

15. Chaney, R. L., Angle, J. S., Li, Y.-M. \& Baker, A. J. M. Recuperation de metaux presents dans des sols (2000).

16. Chaney, R. L. et al. Improved understanding of hyperaccumulation yields commercial phytoextraction and phytomining technologies. J. Environ. Qual. 36, 1429-1443 (2007).

17. Li, Y.-M. et al. Development of a technology for commercial phytoextraction of nickel: Economic and technical considerations. Plant Soil 249, 107-115 (2003).

18. Strawn, K. Unearthing the habitat of a hyperaccumulator: Case study of the invasive plant yellowtuft (Alyssum; Brassicaceae) in Southwest Oregon, USA. Manag. Biol. Invasions 4, 249-259 (2013).

19. Grison, C. et al. Psychotria douarrei and Geissois pruinosa, novel resources for the plant-based catalytic chemistry. RSC Adv. 3 , 22340-22345 (2013).

20. Lange, B. et al. Copper and cobalt mobility in soil and accumulation in a metallophyte as influenced by experimental manipulation of soil chemical factors. Chemosphere 146, 75-84 (2016).

21. Grison, C. M. et al. The leguminous species Anthyllis vulneraria as a Zn-hyperaccumulator and eco-Zn catalyst resources. Environ. Sci. Pollut. Res. 22, 5667-5676 (2015).

22. Escande, V. et al. Ecological catalysis and phytoextraction: Symbiosis for future. Appl. Catal. B 146, 279-288 (2014).

23. Liu, C. et al. Element case studies: Rare earth elements. In Agromining: Farming for Metals (Springer, 2018). https://doi.org/10. 1007/978-3-319-61899-9 19

24. Lahl, U. \& Hawxwell, K. A. REACH-The new European chemicals law. Environ. Sci. Technol. 40, 7115-7121 (2006).

25. Sarrailh, J.-M. La revégétalisation des exploitations minières: lexemple de la Nouvelle-Calédonie. Bois For. Trop. (2002).

26. Losfeld, G. et al. Phytoextraction from mine spoils: Insights from New Caledonia. Environ. Sci. Pollut. Res. 22, 5608-5619 (2015).

27. Garel, C. et al. Structure and composition of first biosourced Mn-rich catalysts with a unique vegetal footprint. Mater. Today Sustain. https://doi.org/10.1016/j.mtsust.2019.100020 (2019).

28. Jaffré, T. Accumulation du manganèse par les Protéacées de Nouvelle Calédonie. Compt. Rend. Acad. Sci. (Paris) Sér. D 289, 425-428 (1979).

29. Jaffré, T. Plantes de Nouvelle Calédonie permettant de revégétaliser des sites miniers (SLN, 1992).

30. Jaffré, T. Accumulation du manganèse par des espèces associées aux terrains ultrabasiques de Nouvelle Calédonie. Compt. Rend. Acad. Sci. Paris Sér. D 284, 1573-1575 (1977).

31. Luçon, S., Marion, F., Niel, J. F. \& Pelletier, B. Réhabilitation des sites miniers sur roches ultramafiques en Nouvelle-Calédonie. In Ecologie des milieux sur roches ultramafiques et sur sols métallifères: actes de la deuxième conférence internationale sur lécologie des milieux serpentiniques Vol. III (eds Jaffré, T. et al.) 297-303 (ORSTOM, 1997).

32. Reeves, R. D. Tropical hyperaccumulators of metals and their potential for phytoextraction. Plant Soil 249, 57-65 (2003).

33. L'Huillier, L. et al. La restauration des sites miniers. In Mines et environnement en Nouvelle Calédonie: les milieux sur substrats ultramafiques et leur restauration (eds L'Huillier, L. et al.) 147-230 (IAC, 2010).

34. Udo, H., Barrault, J. \& Gâteblé, G. Multiplication et valorisation horticole de plantes indigènes à la Nouvelle-Calédonie: Compterendu des essais 2011 (2011).

35. Jaffré, T. Etude écologique du peuplement végétal des sols dérivés de roches ultrabasiques en Nouvelle Calédonie (ORSTOM, 1980).

36. Baker, A., Mcgrath, S., Reeves, R. \& Smith, J. A. C. Metal hyperaccumulator plants: A review of the ecology and physiology of a biological resource for phytoremediation of metal-polluted soils. Phytoremediat. Contamin. Soil Water. https://doi.org/10.1201/ 9780367803148-5 (2000).

37. Bihanic, C., Richards, K., Olszewski, T. K. \& Grison, C. Eco-Mn ecocatalysts: Toolbox for sustainable and green Lewis acid catalysis and oxidation reactions. ChemCatChem 12, 1529-1545 (2020).

38. Pillon, Y., Munzinger, J., Amir, H. \& Lebrun, M. Ultramafic soils and species sorting in the flora of New Caledonia. J. Ecol. 98, $1108-1116(2010)$.

39. Bidwell, S. D., Woodrow, I. E., Batianoff, G. N. \& Sommer-Knudsen, J. Hyperaccumulation of manganese in the rainforest tree Austromyrtus bidwillii (Myrtaceae) from Queensland, Australia. Funct. Plant Biol. 29, 899-905 (2002).

40. Fernando, D. R. et al. Foliar Mn accumulation in eastern Australian herbarium specimens: Prospecting for 'new' Mn hyperaccumulators and potential applications in taxonomy. Ann. Bot. 103, 931-939 (2009).

41. Mizuno, T. et al. Age-dependent manganese hyperaccumulation in Chengiopanax sciadophylloides (Araliaceae). J. Plant Nutr. 31, 1811-1819 (2008).

42. Xue, S. G. et al. Manganese uptake and accumulation by the hyperaccumulator plant Phytolacca acinosa Roxb. (Phytolaccaceae). Environ. Pollut. 131, 393-399 (2004)

43. Yang, S. X., Deng, H. \& Li, M. S. Manganese uptake and accumulation in a woody hyperaccumulator, Schima superba. Plant Soil Environ. 54, 441-446 (2008).

44. Proctor, J., Phillipps, C., Duff, G. K., Heaney, A. \& Robertson, F. M. Ecological studies on Gunung Silam, a small ultrabasic Mountain in Sabah, Malaysia. II. Some Forest Processes. J. Ecol. 77, 317-331 (1989).

45. Graham, R. D., Hannam, R. J. \& Uren, N. C. Manganese in Soils and Plants. https://doi.org/10.1007/978-94-009-2817-6 (Springer Netherlands, 1988).

46. Loneragan, J. F. Distribution and movement of manganese in plants. In Manganese in Soils and Plants (eds Graham, R. D. et al.) 113-124 (Springer Netherlands, 1988). https://doi.org/10.1007/978-94-009-2817-6_9.

47. Taiz, L. \& Zeiger, E. Plant Physiology 3rd edn. (Sinauer Associates Inc., 2002).

48. Burnell, J. N. The biochemistry of manganese in plants. In Manganese in Soils and Plants (eds Graham, R. D. et al.) 125-137 (Springer Netherlands, 1988). https://doi.org/10.1007/978-94-009-2817-6_10.

49. Lidon, F. C., Barreiro, M. G. \& Ramalho, J. C. Manganese accumulation in rice: Implications for photosynthetic functioning. J. Plant Physiol. 161, 1235-1244 (2004).

50. Rengel, Z. Availability of Mn, Zn and Fe in the rhizosphere. J. Soil Sci. Plant Nutr. 15, 397-409 (2015).

51. Schmidt, S. B., Jensen, P. E. \& Husted, S. Manganese deficiency in plants: The impact on photosystem II. Trends Plant Sci. 21, 622-632 (2016)

52. Wissemeier, A. H. \& Horst, W. J. Simplified methods for screening cowpea cultivars for manganese leaf-tissue tolerance. Crop Sci. 31, 435-439 (1991).

53. Joardar Mukhopadhyay, M. \& Sharma, A. Manganese in cell metabolism of higher plants. Bot. Rev. 57, 117-149 (1991).

54. Lynch, J. \& St. Clair, S. Mineral stress: The missing link in understanding how global climate change will affect plants in real world soils. Field Crops Res. 90, 101-115 (2004).

55. Alejandro, S., Höller, S., Meier, B. \& Peiter, E. Manganese in plants: From acquisition to subcellular allocation. Front. Plant Sci 11, $300(2020)$.

56. Shao, J. F., Yamaji, N., Shen, R. F. \& Ma, J. F. The key to Mn homeostasis in plants: Regulation of Mn transporters. Trends Plant Sci. 22, 215-224 (2017).

57. Millaleo, R., Reyes-Diaz, M., Ivanov, A. G., Mora, M. L. \& Alberdi, M. Manganese as essential and toxic element for plants: Transport, accumulation and resistance mechanisms. J. Soil Sci. Plant Nutr. 10, 470-481 (2010).

58. Vázquez, M. D. et al. Localization of zinc and cadmium in Thlaspi caerulescens (Brassicaceae), a metallophyte that can hyperaccumulate both metals. J. Plant Physiol. 140, 350-355 (1992). 
59. Krämer, U., Grime, G. W., Smith, J. A. C., Hawes, C. R. \& Baker, A. J. M. Micro-PIXE as a technique for studying nickel localization in leaves of the hyperaccumulator plant Alyssum lesbiacum. Nucl. Instrum. Methods Phys. Res. Sect. B 130, 346-350 (1997).

60. Küpper, H., Lombi, E., Zhao, F.-J. \& McGrath, S. P. Cellular compartmentation of cadmium and zinc in relation to other elements in the hyperaccumulator Arabidopsis halleri. Planta 212, 75-84 (2000).

61. Küpper, H., Lombi, E., Zhao, F.-J., Wieshammer, G. \& McGrath, S. P. Cellular compartmentation of nickel in the hyperaccumulators Alyssum lesbiacum, Alyssum bertolonii and Thlaspi goesingense. J. Exp. Bot. 52, 2291-2300 (2001).

62. Mesjasz-Przybyłowicz, J., Przybyłowicz, W. \& Pineda, C. Nuclear microprobe studies of elemental distribution in apical leaves of the Ni hyperaccumulator Berkheya coddii. S. Afr. J. Sci. 97, 591 (2001).

63. Robinson, B. H., Lombi, E., Zhao, F. J. \& McGrath, S. P. Uptake and distribution of nickel and other metals in the hyperaccumulator Berkheya coddii. New Phytol. 158, 279-285 (2003).

64. Bidwell, S. D., Crawford, S. A., Woodrow, I. E., Sommer-Knudsen, J. \& Marshall, A. T. Sub-cellular localization of Ni in the hyperaccumulator, Hybanthus floribundus (Lindley) F. Muell. Plant Cell Environ. 27, 705-716 (2004).

65. Memon, A. R., Chino, M., Takeoka, Y., Hara, K. \& Yatazawa, M. Distribution of manganese in leaf tissues of manganese accumulator: Acanthopanax sciadophylloides as revealed by Electronprobe X-Ray Microanalyzer. J. Plant Nutr. 2, 457-476 (1980).

66. Memon, A. R., Chino, M., Hara, K. \& Yatazawa, M. Microdistribution of manganese in the leaf tissues of different plant species as revealed by X-ray microanalyzer. Physiol. Plant. 53, 225-232 (1981).

67. Xu, X. et al. Distribution and mobility of manganese in the hyperaccumulator plant Phytolacca acinosa Roxb. (Phytolaccaceae). Plant Soil 285, 323-331 (2006).

68. Fernando, D. R. et al. Novel pattern of foliar metal distribution in a manganese hyperaccumulator. Funct. Plant Biol. 35, 193 (2008).

69. Fernando, D. R. et al. Foliar manganese accumulation by Maytenus founieri (Celastraceae) in its native New Caledonian habitats: Populational variation and localization by X-ray microanalysis. New Phytol. 177, 178-185 (2008).

70. Fernando, D. R. et al. Manganese accumulation in the leaf mesophyll of four tree species: A PIXE/EDAX localization study. New Phytol. 171, 751-757 (2006).

71. Fernando, D. R. et al. Variability of Mn hyperaccumulation in the Australian rainforest tree Gossia bidwillii (Myrtaceae). Plant Soil 293, 145-152 (2007).

72. Fernando, D. R., Marshall, A., Baker, A. J. M. \& Mizuno, T. Microbeam methodologies as powerful tools in manganese hyperaccumulation research: present status and future directions. Front. Plant Sci. 4, 319 (2013).

73. Fernando, D. R., Woodrow, I. E., Baker, A. J. M. \& Marshall, A. T. Plant homeostasis of foliar manganese sinks: Specific variation in hyperaccumulators. Planta 236, 1459-1470 (2012).

74. Fernando, D. R., Marshall, A. T. \& Green, P. T. Cellular ion interactions in two endemic tropical rainforest species of a novel metallophytic tree genus. Tree Physiol. 38, 119-128 (2018).

75. Bihanic, C. et al. Eco-CaMnOx: A greener generation of eco-catalysts for eco-friendly oxidation processes. ACS Sustain. Chem. Eng. 8, 4044-4057 (2020).

76. Park, Y. J. \& Doeff, M. M. Synthesis and electrochemical characterization of $\mathrm{M} 2 \mathrm{Mn} 3 \mathrm{O} 8(\mathrm{M}=\mathrm{Ca}, \mathrm{Cu})$ compounds and derivatives. Solid State Ion. 177, 893-900 (2006).

77. Harper, F. A. et al. Metal coordination in hyperaccumulating plants studied using EXAFS. In Synchrotron Radiation Department Scientific Reports 102 (eds Murphy, B. et al.) (Central Laboratory of Research Councils, 1999).

78. Rabier, J., Laffont-Schwob, I., Notonier, R., Fogliani, B. \& Bouraïma-Madjèbi, S. Anatomical element localization by EDXS in Grevillea exul var. exul under nickel stress. Environ. Pollut. 156, 1156-1163 (2008).

79. Fernando, D. R., Mizuno, T., Woodrow, I. E., Baker, A. J. M. \& Collins, R. N. Characterization of foliar manganese (Mn) in Mn (hyper)accumulators using X-ray absorption spectroscopy. New Phytol. 188, 1014-1027 (2010).

80. Fritsch, E. Les sols. In Atlas de la Nouvelle Calédonie (eds Bonvallot, J. et al.) 73-76 (IRD, 2012).

81. Isnard, S., L'huillier, L., Rigault, F. \& Jaffré, T. How did the ultramafic soils shape the flora of the New Caledonian hotspot?. Plant Soil 403, 53-76 (2016).

82. Jaffré, T. Composition chimique et conditions de l'alimentation minérale des plantes sur roches ultrabasiques (Nouvelle Calédonie). Cah. ORSTOM. Sér. Biol. 11, 53-63 (1976).

83. Majourau, P. \& Pillon, Y. A review of Grevillea (Proteaceae) from New Caledonia with the description of two new species. Phytotaxa 477, 243-252 (2020).

84. Jaffré, T. \& Latham, M. Contribution à létude des relations sol-végétation sur un massif de roches ultrabasiques de la côte Ouest de la Nouvelle Calédonie: le Boulinda. Adansonia. Série 2(14), 311-336 (1974).

85. L'Huillier, L. et al. Mines et environnement en Nouvelle-Caledonie: les milieux sur substrats ultramafiques et leur restauration (IAC, 2010).

86. Purnell, H. M. Studies of the family Proteaceae. I. Anatomy and morphology of the roots of some Victorian species. Aust. J. Bot. 8, 38-50 (1960).

87. Lamont, B. B. Structure, ecology and physiology of root clusters-A review. Plant Soil 248, 1-19 (2003).

88. Shane, M. W. \& Lambers, H. Manganese accumulation in leaves of Hakea prostrata (Proteaceae) and the significance of cluster roots for micronutrient uptake as dependent on phosphorus supply. Physiol. Plant. 124, 441-450 (2005).

89. Dinkelaker, B., Hengeler, C. \& Marschner, H. Distribution and function of proteoid roots and other root clusters. Bot. Acta 108, 183-200 (1995)

90. Castillo-Michel, H. A., Larue, C., Pradas del Real, A. E., Cotte, M. \& Sarret, G. Practical review on the use of synchrotron based micro- and nano- X-ray fluorescence mapping and X-ray absorption spectroscopy to investigate the interactions between plants and engineered nanomaterials. Plant Physiol. Biochem. 110, 13-32 (2017).

91. Vantelon, D. et al. The LUCIA beamline at SOLEIL. J. Synchrotron Radiat. 23, 635-640 (2016).

92. Solé, V. A., Papillon, E., Cotte, M., Walter, P. \& Susini, J. A multiplatform code for the analysis of energy-dispersive X-ray fluorescence spectra. Spectrochim. Acta Part B 62, 63-68 (2007).

93. Ravel, B. \& Newville, M. ATHENA, ARTEMIS, HEPHAESTUS: Data analysis for X-ray absorption spectroscopy using IFEFFIT. J. Synchrotron Radiat. 12, 537-541 (2005).

94. Schindelin, J. et al. Fiji: An open-source platform for biological-image analysis. Nat. Methods 9, 676-682 (2012).

95. Losfeld, G. L'association de la phytoextraction et de l'écocatalyse : un nouveau concept de chimie verte, une opportunité pour la remédiation de sites miniers. (Montpellier 2, 2014).

96. van der Ent, A. et al. X-ray fluorescence elemental mapping of roots, stems and leaves of the nickel hyperaccumulators Rinorea cf. bengalensis and Rinorea cf. javanica (Violaceae) from Sabah (Malaysia), Borneo. Plant Soil. https://doi.org/10.1007/s11104019-04386-2 (2020).

97. Belli, M. et al. X-ray absorption near edge structures (XANES) in simple and complex Mn compounds. Solid State Commun. 35, 355-361 (1980).

98. van der Ent, A. et al. X-ray elemental mapping techniques for elucidating the ecophysiology of hyperaccumulator plants. New Phytol. 218, 432-452 (2018).

99. Neumann, G. \& Martinoia, E. Cluster roots-An underground adaptation for survival in extreme environments. Trends Plant Sci. 7, 162-167 (2002). 
100. Memon, A. R. \& Yatazawa, M. Nature of manganese complexes in manganese accumulator plant-Acanthopanax sciadophylloides. J. Plant Nutr. 7, 961-974 (1984).

101. Xu, X., Shi, J., Chen, X., Chen, Y. \& Hu, T. Chemical forms of manganese in the leaves of manganese hyperaccumulator Phytolacca acinosa Roxb. (Phytolaccaceae). Plant Soil 318, 197 (2008).

102. Fernando, D. R., Baker, A. J. M. \& Woodrow, I. E. Physiological responses in Macadamia integrifolia on exposure to manganese treatment. Aust. J. Bot. 57, 406 (2009).

103. Fernando, D. R., Batianoff, G. N., Baker, A. J. \& Woodrow, I. E. In vivo localization of manganese in the hyperaccumulator Gossia bidwillii (Benth.) N. Snow \& Guymer (Myrtaceae) by cryo-SEM/EDAX. Plant Cell Environ. 29, 1012-1020 (2006).

104. Léon, V. et al. Effects of three nickel salts on germinating seeds of Grevillea exul var. rubiginosa, an endemic serpentine Proteaceae. Ann. Bot. https://doi.org/10.1093/aob/mci066 (2005).

105. Jaffré, T., Latham, M. \& Schmid, M. Aspects de l'influence de l'extraction du minerai de nickel sur la végétation et les sols en Nouvelle-Calédonie. Cah. ORSTOM. Sér. Biol. 12, 307-321 (1977).

106. Boyd, R. S. \& Martens, S. The raison detre for metal hyperaccumulation by plants (1992).

107. Krämer, U., Pickering, I. J., Prince, R. C., Raskin, I. \& Salt, D. E. Subcellular localization and speciation of nickel in hyperaccumulator and non-accumulator Thlaspi species. Plant Physiol. 122, 1343-1353 (2000).

108. Asemaneh, T., Ghaderian, S. M., Crawford, S. A., Marshall, A. T. \& Baker, A. J. M. Cellular and subcellular compartmentation of $\mathrm{Ni}$ in the Eurasian serpentine plants Alyssum bracteatum, Alyssum murale (Brassicaceae) and Cleome heratensis (Capparaceae). Planta 225, 193-202 (2006).

109. Küpper, H., Jie Zhao, F. \& McGrath, S. P. Cellular compartmentation of zinc in leaves of the hyperaccumulator Thlaspi caerulescens. Plant Physiol. 119, 305-312 (1999).

110. Abubakari, F. et al. Incidence of hyperaccumulation and tissue-level distribution of manganese, cobalt and zinc in the genus Gossia (Myrtaceae). Metallomics https://doi.org/10.1093/mtomcs/mfab008 (2021).

111. White, P. J. Long-distance transport in the xylem and phloem, chapter 3. In Marschner's Mineral Nutrition of Higher Plants 3rd edn (ed. Marschner, P.) 49-70 (Academic Press, 2012). https://doi.org/10.1016/B978-0-12-384905-2.00003-0.

112. Marschner, H. Marschner's Mineral Nutrition of Higher Plants (Academic Press, 2012). https://doi.org/10.1016/C2009-0-63043-9.

113. Fernando, D. R. et al. Does foliage metal accumulation influence plant-insect interactions? A field study of two sympatric tree metallophytes. Funct. Plant Biol. 45, 945-956 (2018).

114. Pearson, R. G. Hard and soft acids and bases, HSAB, part 1: Fundamental principles. J. Chem. Educ. 45, 581 (1968).

115. Alejandro, S., Höller, S., Meier, B. \& Peiter, E. Manganese in plants: From acquisition to subcellular allocation. Front. Plant Sci. 11, $300(2020)$.

116. Hirschi, K. D., Korenkov, V. D., Wilganowski, N. L. \& Wagner, G. J. Expression of Arabidopsis CAX2 in tobacco. Altered metal accumulation and increased manganese tolerance. Plant Physiol. 124, 125-134 (2000).

117. Wu, Z. et al. An endoplasmic reticulum-bound $\mathrm{Ca}(2+) / \mathrm{Mn}(2+)$ pump, ECA1, supports plant growth and confers tolerance to $\mathrm{Mn}(2+)$ stress. Plant Physiol. 130, 128-137 (2002).

118. Pittman, J. K. Managing the manganese: Molecular mechanisms of manganese transport and homeostasis. New Phytol. 167, 733-742 (2005)

119. Mills, R. F. et al. ECA3, a Golgi-localized P2A-type ATPase, plays a crucial role in manganese nutrition in Arabidopsis. Plant Physiol. 146, 116-128 (2008).

120. Mizuno, T., Emori, K. \& Ito, S. Manganese hyperaccumulation from non-contaminated soil in Chengiopanax sciadophylloides Franch. et Sav. and its correlation with calcium accumulation. Soil Sci. Plant Nutr. 59, 591-602 (2013).

121. Tordoff, G. M., Baker, A. J. M. \& Willis, A. J. Current approaches to the revegetation and reclamation of metalliferous mine wastes. Chemosphere 41, 219-228 (2000).

122. Grossnickle, S. \& Ivetic, V. Direct seeding in reforestation-A field performance review. REFORESTA https://doi.org/10.21750/ REFOR.4.07.46 (2017).

123. Bermúdez-Contreras, A. I., Ede, F., Waymouth, V., Miller, R. \& Aponte, C. Revegetation technique changes root mycorrhizal colonisation and root fungal communities: The advantage of direct seeding over transplanting tube-stock in riparian ecosystems. Plant Ecol. https://doi.org/10.1007/s11258-020-01031-2 (2020).

\section{Acknowledgements}

We acknowledge CNRS and SOLEIL for provision of synchrotron radiation facilities (proposal 20181459). We also thank SLN for our collaboration and Northern Province of New Caledonia for harvest authorizations (609011-40/2019/DEPART/JJC). Finally, Sci-GuidEdit company is acknowledged for writing assistance and proofreading the article.

\section{Author contributions}

C.G. conceived and designed the study. C.B., A.G., C.P., C.R., R.P., F.P. and L.C. carried out the harvest, preparation of samples and analyses. M.H., C.G., C.B., C.R., D.McK and E.P. completed integrated data analyses and wrote the paper.

\section{Competing interests}

The authors declare no competing interests.

Additional information

Supplementary Information The online version contains supplementary material available at https://doi.org/ 10.1038/s41598-021-03151-9.

Correspondence and requests for materials should be addressed to C.G.

Reprints and permissions information is available at www.nature.com/reprints.

Publisher's note Springer Nature remains neutral with regard to jurisdictional claims in published maps and institutional affiliations. 
(c) (i) Open Access This article is licensed under a Creative Commons Attribution 4.0 International cc) License, which permits use, sharing, adaptation, distribution and reproduction in any medium or format, as long as you give appropriate credit to the original author(s) and the source, provide a link to the Creative Commons licence, and indicate if changes were made. The images or other third party material in this article are included in the article's Creative Commons licence, unless indicated otherwise in a credit line to the material. If material is not included in the article's Creative Commons licence and your intended use is not permitted by statutory regulation or exceeds the permitted use, you will need to obtain permission directly from the copyright holder. To view a copy of this licence, visit http://creativecommons.org/licenses/by/4.0/.

(C) The Author(s) 2021 